\title{
Hindbrain $5^{\prime}$-adenosine monophosphate-activated protein kinase Mediates Short-Term Food Deprivation Inhibition of the Gonadotropin-Releasing Hormone-Luteinizing Hormone Axis: Role of Nitric Oxide
}

\author{
Manita Shakya, Prem K. Shrestha, and Karen P. Briski \\ Department of Basic Pharmaceutical Sciences, School of Pharmacy, College of Health and \\ Pharmaceutical Sciences, University of Louisiana Monroe, Monroe, LA 71201
}

\begin{abstract}
Hindbrain-derived stimuli restrain the gonadotropin-releasing hormone $(\mathrm{GnRH})$-pituitary luteinizing hormone (LH) reproductive neuroendocrine axis during energy insufficiency. Interruption of food intake, planned or unplanned, is emblematic of modern life. This study investigated the premise that the hindbrain energy sensor adenosine $5^{\prime}$-monophosphate-activated protein kinase (AMPK) inhibits reproductive neuroendocrine function in short-term, e.g. $18 \mathrm{hr}$ food-deprived (FD) estradiol (E)-implanted ovariectomized female rats. Intra-caudal fourth ventricular administration of the AMPK inhibitor Compound C (Cc) reversed FD-induced inhibition of rostral preoptic (rPO) $\mathrm{GnRH}$ protein expression and $\mathrm{LH}$ release in animals given $\mathrm{E}$ to replicate proestrus- (high-E dose), but not metestrus (low-E dose)-stage plasma steroid levels. FD caused Cc-reversible augmentation or diminution of preoptic norepinephrine (NE) activity in highversus low-E rats, respectively, and AMPK-independent reductions in hypothalamic NE accumulation in the latter. Nitric oxide (NO) and kisspeptin are key stimulatory signals for the preovulatory LH surge. Here, FD inhibited rPO neuronal nitric oxide synthase protein expression in high-, but not low-E - dosed animals. Lateral ventricular delivery of the NO donor SIN-1 reversed inhibitory GnRH and LH responses to FD in high-E rats, and normalized rPO Vglut2, anteroventral periventricular KiSS1, and dorsomedial hypothalamic RFRP-3 mRNA and/or protein profiles. Data show that FD curtails reproductive neuroendocrine outflow by hindbrain AMPKdependent mechanisms in the presence of peak estrous cycle E levels. Results indicate that neural networks linking this sensor to GnRH neurons likely involve NO signaling, which may function upstream of one or more neurotransmitters identified here by SIN-1 - reversible inhibitory responses to FD.
\end{abstract}

Correspondence: Dr. Karen P. Briski, Ph.D., Professor of Pharmacology and Neuroanatomy, Head, Department of Basic Pharmaceutical Sciences, School of Pharmacy, College of Health and Pharmaceutical Sciences, The University of Louisiana at Monroe, 356 Bienville Building, 1800 Bienville Drive, Monroe, LA 71201, TEL: 318-342-3283, FAX: 318-342-1737, briski@ulm.edu.

Publisher's Disclaimer: This is a PDF file of an unedited manuscript that has been accepted for publication. As a service to our customers we are providing this early version of the manuscript. The manuscript will undergo copyediting, typesetting, and review of the resulting proof before it is published in its final form. Please note that during the production process errors may be discovered which could affect the content, and all legal disclaimers that apply to the journal pertain. 


\section{Keywords}

Food deprivation; estradiol; norepinephrine; GnRH-I; luteinizing hormone; neuronal nitric oxide synthase; KiSS1

\section{Introduction}

Clinical and experimental studies document strict control of reproduction in female mammals by metabolic status. Negative energy balance impairs fecundity in women, food animals, and laboratory species. Female reproduction (encompassing ovulation, conception, pregnancy, and lactation) is a high energy-cost activity; its impedance or suspension under such circumstances is logical as successful conclusion of this complex process is likely to be jeopardized and energy investment thereby wasted [Wade and Jones, 2004]. Specialized neurons in the caudal hindbrain continuously monitor cellular energy state [Oomura and Yoshimatsu, 1984]. Indeed, the hindbrain, not the hypothalamus, is the primary source of metabolic deficit cues that curb pituitary luteinizing hormone (LH) secretion [Ohkura et al., 2000]. Provision of glucose anti-metabolite drugs to the hindbrain suppresses GnRH neuron transcriptional activation and LH release, evidence that affirms a functional link between hindbrain metabolic sensors and the gonadotropin-releasing hormone (GnRH)-LH neuroendocrine axis [Singh and Briski, 2004a; Ibrahim and Briski, 2014].

Maintenance of energy homeostasis despite variable environmental nutrient provision and dynamic adjustments in internal energy needs poses a constant challenge. Eating behavior is a complex interplay of physiological, psychological, social, and genetic factors that influence meal timing, quantity of food intake, and food preference. The ideal circumstance of unfettered ability to eat-at-will in response to the above drives can be impractical in reality. Indeed, short-term suspension of food intake, planned or unplanned, is an unavoidable and unpredictable metabolic stressor inherent to modern life. Interrupted feeding over several hours elicits estradiol (E)-dependent patterns of hyperphagia and adjustments in circulating substrate fuel and energy deficit-sensitive hormone levels in ovariectomized (OVX) female rats [Ibrahim and Briski, 2015; Alenazi et al., 2016; Briski et al., 2016]. The ultra-sensitive energy sensor adenosine $5^{\prime}$-monophosphate-activated protein kinase (AMPK) acts within the caudal dorsomedial hindbrain to control feeding and forebrain AMPK and metabolic neuropeptide responses to short-term food deprivation (FD) [Alenazi et al., 2016]. A2 noradrenergic neurons are a plausible source of E-sensitive AMPK cues originating within that site as this neurochemical phenotype is the sole local cell population that is identified so far as AMPK-positive and, moreover, is capable of integrating steroidal and metabolic stimuli by virtue of estrogen receptor-alpha and -beta protein expression [Ibrahim et al., 2013]. E modulates effects of caudal hindbrain administration of the AMP mimic 5-aminoimidazole-4-carboxamide-riboside (AICAR) on AMPK activity in hindbrain metabolo-sensory A2 noradrenergic neurons [Ibrahim et al., 2013] and on sensor activation and metabolic neuropeptide transmitter expression in downstream hypothalamic loci [Alenazi et al., 2014]. Estrogen establishes preoptic and hypothalamic targets of hindbrain AMPK-impelled NE signaling in ovariectomized (OVX) female rats [Alenazi et al., 2016]. E likely modulates reproductive neuroendocrine sensitivity 
to energy debit as hormone-replaced OVX rats exhibit amplified anti-glucose metaboliteinduced suppression of LH output [Nagatani et al., 1996]. Pituitary-gonadal hormones exhibit rapid reactivity to nutritional signals [Cameron and Norbisch, 1991; Schreihofer et al., 1993]. The current study investigated the hypothesis that female reproductive neuroendocrine function is vulnerable to FD inhibition involving caudal hindbrain AMPKdependent mechanisms.

E acts on the female brain to impose opposing negative/positive feedback actions on the GnRH-LH axis, and to regulate metabolic status via control of energy intake, storage, and expenditure. E secretion fluctuates dramatically over the female rat estrous cycle, increasing 4-5 fold from nadir to peak circulating levels. Basal plasma E levels inhibit reproductive neuroendocrine function, whereas the mid-cyclic increase in circulating $\mathrm{E}$ amplifies $\mathrm{GnRH}$ output to the anterior pituitary, which in turn initiates the the proestrus pre-ovulatory LH surge. This dual mode of estrogenic control is accomplished, in part, by distinctive patterns of norepinephrine (NE) neurotransmission to the preoptic area/hypothalamus [Wise et al., 1981; Adler et al., 1983; Demling et al., 1985]. Cycle stage-specific patterns of E release impact metabolic stasis as food intake declines and energy state becomes (paradoxically) more negative as levels of this hormone levels rise [Giles et al., 2010]. The present project utilized a characterized E replacement paradigm that re-establishes plasma hormone levels at estrous cycle peak versus nadir concentrations [Goodman, 1978; Briski et al., 2001] to determine if physiologically distinct patterns of E secretion exert distinguishing control of caudal dorsomedial hindbrain AMPK-driven NE input to reproduction-relevant forebrain structures alongside GnRH-LH axis reactivity to short-interval FD in female rats.

Micropunch-dissected loci evaluated for FD-mediated changes in NE activity in low- versus high-E - replaced OVX female rats included structures [e.g. rostral preoptic area (rPO) and anteroventral periventricular (AVPV), medial preoptic (MPN), and hypothalamic arcuate (ARH) nuclei] previously reported to exhibit adjusted neurotransmitter content during hypoglycemic metabolic stress [Briski and Shrestha, 2016]. A related aim of the current project was to identify neurochemicals within discernible forebrain targets of FD-triggered NE signaling that may potentially link hindbrain AMPK with the GnRH-LH axis during this metabolic stress. Effects of FD on the E-sensitive neurotransmitters nitric oxide (NO) [Watanobe et al 2001; Moreno and Franci, 2004; Lima et al., 2014], $\boldsymbol{\gamma}$-amino-butyric acid (GABA) [Leonhardt et al., 1999], kisspeptin [Luque et al., 2007], glutamate [Brann and Mahesh, 1997], RFamide-related peptide-3 (RFRP-3) [Gibson et al., 2008; Klingerman et al., 2011; Leon et al., 2014], neuropeptide Y (NPY) [Pelletier et al., 1992; Jovanovic et al., 2010; Sainsbury and Zhang, 2010; Señarís et al., 2011], and proopiomelanocortin (POMC) [Bohler et al., 1990; Wise et al., 1990; Jovanovic et al., 2010; Sainsbury and Zhang, 2010; Señarís et al., 2011], were evaluated using high-sensitivity quantitative real-time RT-PCR and Western blotting for analysis of micropunch tissue samples containing neurons that synthesize these neurochemicals. 


\section{Methods and Materials}

\section{Animals}

Adult female Sprague Dawley rats (2-3 months of age) were maintained under a $14 \mathrm{hr}$ light/10 hr-dark lighting schedule (lights on at 05:00h), and permitted free access to standard laboratory rat chow (Harlan Teklad LM-485; Harlan Industries, Madison, WI, USA) and tap water. Rats were handled daily for 7 days prior to experimentation. All protocols were conducted in accordance with NIH guidelines for care and use of laboratory animals, with approval by the ULM Institutional Animal Care and Use Committee.

\section{Experimental Design}

Experiment 1-On day 1, rats were bilaterally OVX and implanted with a PE-20 polyethylene cannula aimed at the caudal fourth ventricle (CV4) under ketamine/xylazine (0.1 mL/100 g bw i.p.; $90 \mathrm{mg}$ ketamine/10 mg xylazine/mL; Henry Schein, Inc., Melville, NY, USA), as described [Singh and Briski, 2004a]. After surgery, animals were treated with Enrofloxacin (Baytril 2.27\%, $10 \mathrm{mg} / \mathrm{kg} b w$, intramuscular) and Ketoprofen [3 mg/kg $b w$, subcutaneous (sc)], and transferred to individual housing after surgery. On day 7 , animals were anesthetized with isoflurane (5\% for induction; $2.5 \%$ for maintenance) prior to $s c$ implantation of a silastic capsule [ $10 \mathrm{~mm} / 100 \mathrm{~g} b w, 0.062$ in. i.d/ $/ 0.125$ in. o.d.] containing $17 \beta$-estradiol-3-benzoate at a concentration of either 30 (E-30) or $300(\mathrm{E}-300) \mu \mathrm{g} / \mathrm{mL}$ safflower oil. We reported that these disparate $\mathrm{E}$ doses yield circulating hormone levels that mimic plasma $\mathrm{E}$ levels measured on metestrus or proestrus, respectively, [Butcher et al., 1974] in ovary-intact female rats [Briski et al., 2001]. Groups of E-30 and E-300 rats were treated as follows: 1) full-fed (FF) plus intra-CV4 vehicle (V) dimethyl sulfoxide (DMSO) administration at $15.00 \mathrm{hr}$ on day 11/[n=4 E-30; $\mathrm{n}=4 \mathrm{E}-300]$; 2) FD (initiated at $21.00 \mathrm{hr}$ on day 10) plus CV4 V treatment at $15.00 \mathrm{hr}$ on day 11 [n=4 E-30; n=4 E-300]; 3) FD plus CV4 administration of the AMPK inhibitor Compound C (Cc; $5.0 \mu \mathrm{g} / 2.0 \mathrm{uL}$ DMSO) at $15.00 \mathrm{hr}$ on day 11 [n=4 E-30; n=4 E-300]. Animals were sacrificed at $16.00 \mathrm{hr}$ on day 11. Brains were cut into 100 micron-thick fresh frozen sections for micropunch dissection of individual preoptic/hypothalamic structures of interest. Trunk blood was collected for LH radioimmunoassay.

Experiment 2-On day 1, OVX rats were implanted with a PE-20 cannula into the left lateral cerebral ventricle (LV) [Singh and Briski, 2004a]. Animals received a $s c$ silastic capsule $[10 \mathrm{~mm} / 100 \mathrm{~g} b w ; 0.062$ in. i.d/0.125 in. o.d.] filled with 300 (E-300) $\mu$ g estradiol benzoate $/ \mu \mathrm{g} / \mathrm{mL}$ safflower oil. Groups of E-300 rats (n=5/group) were treated as follows: 1 ) full-fed (FF) plus LV administration of the vehicle saline (V) at $15.00 \mathrm{hr}$ on day 11;2) FD (initiated at $21.00 \mathrm{hr}$ on day 10) plus intra-LV delivery of $\mathrm{V}$ at $15.00 \mathrm{hr}$ on day 11 ; 3) FD plus LV 3-morpholinosydnonimine (SIN-1; $100 \mu \mathrm{g} / 2.0 \mathrm{uL}$ ) [Yokotani et al., 1997; Briski, 1999] at $15.00 \mathrm{hr}$ on day 11 ; 4) FD plus intra-LV administration of $200 \mu \mathrm{g} / \mathrm{SIN}-1$ at $15.00 \mathrm{hr}$ on day 11. Animals were sacrificed at $16.00 \mathrm{hr}$ on day 11. Brains were cut into 100 micronthick fresh frozen sections for micropunch dissection of preoptic/hypothalamic structures of interest. Trunk blood was obtained for LH radioimmunoassay. 


\section{Brain tissue micro-punch dissection}

Calibrated hollow needles ( $0.5 \mathrm{~mm}$ diameter; prod. no. 57401, Stoelting, Inc., Kiel, WI), were used to bilaterally dissect the following neural structures (relative to bregma) from serial frozen brain sections, using described methods [Singh and Briski, 2004b]: Experiment 1: $\mathrm{rPO}$ [+0.3 to $0.00 \mathrm{~mm}]$; AVPV [ -0.00 to $-0.26 \mathrm{~mm}$ ]; MPN [ -0.26 to $-0.60 \mathrm{~mm}$ ]; paraventricular hypothalamic nucleus [PVN; -1.78 to $-2.00 \mathrm{~mm}$ ]; ARH [-1.78 to -3.25 $\mathrm{mm}$ ]; ventromedial hypothalamic nucleus [VMN; -2.00 to $-3.25 \mathrm{~mm}$ ]; dorsomedial hypothalamic nucleus [DMN; -2.45 to $-3.25 \mathrm{~mm}$ ]; lateral hypothalamic area [LHA; -1.78 to $-3.28 \mathrm{~mm}$ ]. For each neural structure of interest, tissues harvested from separate sides of the forebrain were collected into appropriate buffers for NE ELISA (0.01N HCL containing $1 \mathrm{mM}$ EDTA and $4 \mathrm{mM}$ sodium metabisulfite) or Western blot (2\% SDS, $0.05 \mathrm{M}$ DTT, 10\% glycerol, $1 \mathrm{mM}$ EDTA, $60 \mathrm{mM}$ Tris-HCl, $\mathrm{pH} 7.2$ ) analyses. Experiment 2: rPO [+0.30 to $0.00 \mathrm{~mm}$ ]; AVPV [0.00 to $-0.26 \mathrm{~mm}$ ]; ARH [ -1.78 to $-3.25 \mathrm{~mm}$ ]; DMN [ -2.45 to -3.25 $\mathrm{mm}$. For each structure described above, tissues harvested from right and left hemiforebrains were respectively collected into buffer for quantitative real-time RT-PCR (guanidinium isothiocynate and $\beta$-mercaptoethanol) or Western blot analyses.

\section{Brain Tissue NE ELISA Analysis}

For each brain structure of interest, aliquots from individual subjects were pooled to create triplicate samples, for each treatment group, for NE content analysis using Noradrenaline Research ELISA ${ }^{\mathrm{TM}}$ kit reagents (Labor Diagnostika Nord GmbH \& Co KG, Nordhorn, Germany) [Shrestha et al., 2014]. Briefly, standards (10 $\mu \mathrm{L})$, controls $(10 \mu \mathrm{L})$ and sample aliquots $(25 \mu \mathrm{L})$ were pipetted in into duplicate extraction plate wells and diluted to $100 \mu \mathrm{L}$ with distilled water. Plates were sequentially incubated by shaking at $600 \mathrm{rpm}$ with TE buffer $(25 \mu \mathrm{L})$, acylation buffer $(150 \mu \mathrm{L})$ plus acylation reagent $(25 \mu \mathrm{L})$, and hydrochloric acid $(100 \mu \mathrm{L}) .90 \mu \mathrm{L}$ of extracted samples, standards, and controls were transferred to individual microtiter plate wells, mixed with enzyme solution $(25 \mu \mathrm{L})$, and incubated for $37^{\circ} \mathrm{C}$ for $2 \mathrm{hr}$. Sample, standard, and control wells aliquots (100 $\left.\mu \mathrm{L}\right)$ were transferred to precoated Noradrenaline Microtiter strip wells, mixed with $50 \mu \mathrm{L}$ of primary antiserum, then incubated for $18 \mathrm{hr}$ at $2-8{ }^{\circ} \mathrm{C}$. After plate contents were discarded, wells were washed $4 \mathrm{X}$, then incubated with enzyme conjugate $(100 \mu \mathrm{L})$ for $30 \mathrm{~min}$. Wells were emptied, washed $4 \mathrm{X}$, then incubated for $30 \mathrm{~min}$ with $100 \mu \mathrm{L}$ substrate. After termination of reactions with 100 $\mu \mathrm{L}$ stop solution, absorbance of well contents was read at $450 \mathrm{~nm}$ in an Emax Precision Microplate Reader (Molecular Devices, LLC, Sunnyvale, CA, USA). Assay sensitivity was $0.1 \mathrm{ng} / \mathrm{ml} \times \mathrm{C}^{*}\left[\mathrm{C}^{*}(\right.$ Correction factor $)=$ volume of standards extracted $/$ sample volume extracted].

\section{Brain Tissue Western Blot Analysis}

Heat-denatured micropunch tissues obtained in Experiment 1 were evaluated as previously described [Gujar et al., 2013]. In each treatment group, aliquots from individual subjects were pooled to create triplicate samples for immunoblotting of each protein of interest. Proteins were separated on 10-15\% gradient Tris-glycine gels (90 V, 105 min; Tris-glycine SDS running buffer) and transblotted ( $30 \mathrm{~V}$, overnight at $4{ }^{\circ} \mathrm{C}$; Towbin buffer) to $0.45-\mu \mathrm{m}$ PVDF membranes. After pretreatment with Pierce Western blotting signal enhancer, 
membranes were blocked with Tris-buffer saline (TBS), pH 7.4, 0.1\% Tween-20 containing either $2 \%$ bovine serum albumin or $5 \%$ normal donkey serum. Proteins from various structures were probed with one of the following primary antibodies: $\underline{\mathrm{PO}}$ : rabbit antipAMPK $_{\mathrm{a} 1 / 2}$ (Thr 172) [1:1000, sc-33524; Santa Cruz Biotechnol., Inc., Santa Cruz, CA], mouse anti-GnRH1 (HU11B) [1:1000, sc-32292; Santa Cruz Biotechnol.), rabbit antiNOS1/neuronal nitric oxide synthase (nNOS) [1:1000, sc-648; Santa Cruz Biotechnol.], goat anti-GAD $65 / 67$ (C-20) [1:1000, sc-7513; Santa Cruz Biotechnol.]; AVPV: goat antikisspeptin (C-20) [1:1000, sc-18134; Santa Cruz Biotechnol.]. The housekeeping protein atubulin was detected with mouse monoclonal antibodies (1:1,000; EMD Millipore, Billerica, MA). Membranes were incubated for $1 \mathrm{hr}$ with peroxidase-conjugated goat anti-mouse (1:5000; PerkinElmer, Boston, MA), goat anti-rabbit (1:5000; PerkinElmer), or donkey antigoat (1:5000; sc-2020; Santa Cruz Biotechnol.) secondary antisera, followed by Supersignal West Femto maximum sensitivity chemiluminescent substrate (ThermoFisherScientific, Rockford, IL). Signal visualization was recorded using a Syngene G:Box Chemi (Syngene, Frederick, MD). Protein band optical densities (O.D.) were quantified with Syngene Genetool 4.01 software and normalized to a-tubulin. Immunoblots were performed in triplicate for each target protein. Protein molecular weight markers were included in each Western blot analysis. Proteins in micropunch samples obtained in Experiment 2 were separated as described above, except that BioRad TGX 10-12\% stain-free gels were used [Colella et al., 2012; Gurtler et al., 2013; Gilda and Gomes, 2013, 2015]. After electrophoresis, gels were activated for 1 min by UV light in a BioRad ChemiDoc TM Touch Imaging System prior to protein transfer to PVDF membranes. After blocking, membranes were incubated with one of the following primary antisera: rPO: mouse antiGnRH1 (see above), mouse anti-vesicular glutamate transporter-2 (Vglut2) [1:1000, MAB5504; EMD Millipore, Temecula, CA], rabbit anti-nNOS (see above); AVPV: goat anti-kisspeptin (see above); $\underline{\mathrm{ARH}}$ : goat anti-kisspeptin (see above), goat anti-neuropeptide $\mathrm{Y}$ (NPY) [1:2000, NBP1-46535; Novus Biologicals], goat anti-proopiomelanocortin (POMC) [1:2000, NB100-1533; Novus Biologicals, Littleton, CO]; DMN: goat anti-RFamide-related peptide-3 (RFRP-3) (M-18) [1:500, sc-32380; Santa Cruz Biotechnol.). Membranes were incubated sequentially with horseradish peroxidase-labeled secondary antisera, as described above, and SuperSignal West Femto Maximum Sensitivity substrate. Total in-lane protein and chemiluminescence band O.D. values were measured densitometrically with BioRad Image Lab 3.0.1 software. Protein bands were normalized to total protein content of their respective lane. Immunoblots were performed in triplicate for each target protein. Protein molecular weight markers were included in each Western blot analysis.

\section{Quantitative Real-Time RT-PCR Analysis of Micropunched Forebrain Loci}

Total RNA was isolated from micropunch tissue samples of individual neural structures using Qiagen RNeasy MiniElute Cleanup kit reagents. For each structure, RNA integrity, purity, and quantity was determined using an Agilent Technologies 2100 Bioanalyzer and Agilent RNA 6000 nano kits. Total RNA was transcribed into first-strand cDNA with Invitrogen SuperScript ${ }^{\mathrm{TM}}$ III Reverse Transcriptase. Forward and reverse primers for target genes were designed with Beacon Designer software (Premier Biosoft International, Palo Alto, CA): GnRH-I [forward: CACTATGCTCACCAGCGGGG; reverse: AGAGCTCCTCGCAGATCCCT-AAGA]; Vglut-2 [forward: TCCCTCGGACAGATCTAC; 
reverse: CATAGCGGAGCCTTCTTC], metastasis-suppressor KiSS-1 (KiSS1) [forward: TGGCACCTGTGGTGAACCCTGACC; reverse: ATCAGGCGACTGCGGGTGGCA-CA], NPY [forward: TGTTTGGGCATTCTGGCTGAGG; reverse: CTGGGGGCATTTTCTGTGCTTT-C], POMC [ forward: CTCCTGCTTCAGACCTCCATAGAC; reverse: AAGGGCTGTTCATCTCCGT-TG], RFRP-3 [forward: GAGTCCTGGTCAAGAGCAAC; reverse: ACTGGCTGGAGGTTTCCTAT], GAPDH [forward: AAGTTCAACGGCACAGTCAAGG; reverse: CATACTCAGCACCAGCATCAC-C], CypA [forward: ATAATGGCACTGGTGGCAAGTC; reverse: ATTCCTGGACCCAAAACGCTC-C], and obtained from Genemed Synthesis (San Antonio, TX). PCR reactions with SYBR Greenbased detection were performed, as described [Vavaiya et al., 2007; Vavaiya and Briski, 2007; 2008], in a BioRad i $Q^{\mathrm{TM}} 5$ iCycler system as follows: initial 3 min denaturation at $95^{\circ} \mathrm{C}$, followed by 40 cycles of denaturation at 1) $95^{\circ} \mathrm{C}$ for $\left.15 \mathrm{sec}, 2\right)$ temperature-specific

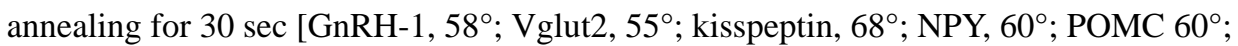
RFRP-3, $50^{\circ}$; GAPDH, $30^{\circ}$; CypA, $58^{\circ}$ ], and 3) extension at $72^{\circ} \mathrm{C}$ for $30 \mathrm{sec}$. No-template and -RT controls and melt curve analyses were performed for each RT-PCR analysis. Amplified PCR products were evaluated by agarose gel electrophoresis. mRNA data were analyzed by the $2^{\wedge}(-\Delta \Delta \mathrm{Ct})$ method.

\section{LH Radioimmunoassay}

Plasma LH concentrations were measured by radioimmunoassay, as described [Singh and Briski, 2004].

\section{Statistical analyses}

Mean tissue NE, mRNA, and normalized protein O.D. values and plasma LH levels were evaluated by one- or two-way ANOVA, according to experimental design, and Duncan's multiple range test. Differences of $p<0.05$ were considered significant.

\section{Results}

Experiment 1 sought to determine if E concentration regulates forebrain targets of caudal hindbrain AMPK-driven NE signaling in response to FD. Figure 1 Panels A-C depict FD effects on NE accumulation in distinctive preoptic loci involved in reproduction, e.g. rPO (A), AVPV (B), and MPN (C), in OVX rats replaced with E to mimic baseline (E-30) or peak (E-300) plasma E concentrations. FD-exposed E-30 animals exhibited significant suppression of NE content in the $\mathrm{rPO}$ and MPN compared to FF controls $\left[\mathrm{E}-30 / \mathrm{FD} / \mathrm{V}_{\mathrm{CV}} 4\right.$ versus $\left.\mathrm{E}-30 / \mathrm{FF} / \mathrm{V}_{\mathrm{CV} 4}\right]$; intra-CV4 Cc administration reversed this response in the $\mathrm{rPO}$ only $\left[\mathrm{E}-30 / \mathrm{FD} / \mathrm{Cc}_{\mathrm{CV} 4}\right.$ versus E-30/FD/ $\left.\mathrm{V}_{\mathrm{CV} 4}\right]$. Yet, in E-300 rats, FD caused Cc-reversible augmentation of NE levels in each preoptic site $\left[\mathrm{E}-300 / \mathrm{FD} / \mathrm{V}_{\mathrm{CV} 4}\right.$ versus E-300/FF/ $/ \mathrm{V}_{\mathrm{CV}}$ / E-300/FD/Cc $\left.\mathrm{CV}_{4}\right]$. FD-associated adjustments in NE accretion in hypothalamic metabolic structures are illustrated in Panels D-H. In these locations, E-30/FD/ $\mathrm{V}_{\mathrm{CV} 4}$ animals were characterized by diminished NE content, which was not normalized by Cc. At the same time, the E-300/FD/ $/ \mathrm{V}_{\mathrm{CV} 4}$ group showed an increase in DMN NE (2E), which was reversed by Cc. Results show that caudal hindbrain AMPK regulates preoptic NE input during FD, 
where recipient sites and directionality of NE response vary in line with estrous cycle peakversus nadir-like E levels.

Firsthand evidence here for AMPK-dependent NE signaling to the rPO, which encompasses a metabolic-sensitive subset of GnRH neurons [Briski and Sylvester, 1998], bolstered a related aim to examine whether GnRH-I and key rPO (NOS, GABA) and AVPV (kisspeptin) upstream neurochemicals exhibit similar or divergent reactivity to FD in E-30 versus E-300 animals. Figure 2 portrays effects of FD on rPO profiles of pAMPK (Panel A), GnRH-I (Panel B), nNOS (Panel C) and GAD $65 / 67$ (Panel D) protein profiles and AVPV kisspeptin protein expression (Panel E) in E- (E-30 versus E-300) implanted OVX rats. Panel F depicts representative Western blots of target proteins. E-300/FF/ $\mathrm{V}_{\mathrm{CV} 4}$ animals showed elevated rPO pAMPK, GnRH-1, and nNOS expression relative to E-30/FF/ $\mathrm{V}_{\mathrm{CV} 4}$. FD-exposed E-30 animals exhibited increased pAMPK protein, a response that was abolished by $\mathrm{Cc}$, but no change in other proteins evaluated. In E-300 rats, rPO pAMPK levels did not differ between $\mathrm{FF} / \mathrm{V}_{\mathrm{CV} 4}$ and $/ \mathrm{FD} / \mathrm{V}_{\mathrm{CV} 4}$ groups, whereas FD caused Cc-revocable reductions in GnRH-I and nNOS profiles $\left[\mathrm{E}-300 / \mathrm{FD} / \mathrm{V}_{\mathrm{CV} 4}\right.$ versus E-300/FF/ $\left./ \mathrm{V}_{\mathrm{CV} 4} / \mathrm{E}-300 / \mathrm{FD} / \mathrm{Cc}_{\mathrm{CV} 4}\right]$. AVPV kisspeptin protein content was significantly greater in FF E-300 versus FF E-30 animals. FD caused a trend toward decreased kisspeptin expression that did not reach statistical significance in either E-30 or E-300 animals. AVPV kisspeptin content was significantly decreased in the E-300/FD/Cc $\mathrm{CV}_{\mathrm{C}}$ group compared to E-300/FF/ $\mathrm{V}_{\mathrm{CV}}$. Data point to caudal hindbrain AMPK-dependent FD inhibition of rPO GnRH-I and NOS protein expression in the presence of estrous cycle peak, but not nadir E levels.

Effects of CV4 Cc administration on FD-associated adjustments in pituitary LH secretion in E-30 versus E-300 animals are shown in Figure 3. Outcomes reveal that FD suppressed circulating LH levels in E-300, but not E-30 rats, and that inhibitory patterns of hormone output in the former group were normalized by intra-CV4 administration of Cc.

Experiment 2 addressed the premise that NO down-regulation is crucial for FD suppression of GnRH-1 in E-300 rats. The excitatory neurotransmitter glutamate is a critical stimulus for the mid-cycle LH surge via actions that include NO up-regulation [Brann et al., 1997]. In order to assess FD effects on rPO glutaminergic function, expression of Vglut2 (the predominant vesicular glutamate transporter isoform expressed by glutamate neurons in the rPO [Lin et al., 2003]) was measured as an indicator of signaling activity. Data in Figure 4 depict impact of LV administration of the NO donor SIN-1 to FD-exposed E-300 animals concerning rPO GnRH-1 and Vglut2 mRNA and protein content. rPO GnRH-1 and Vglut2 mRNAs (Panels A and C, respectively, were insensitive to FD, but were each significantly elevated alongside GnRH-1 (Panel B) and Vglut2 (Panel D) proteins in response to the lower (e.g. $100 \mu \mathrm{g})\left[\mathrm{FD} / \mathrm{S}(100)_{\mathrm{LV}}\right.$ versus FD/V $\left.\mathrm{LV} / \mathrm{FF} / \mathrm{V}_{\mathrm{LV}}\right]$, but not higher $(200 \mu \mathrm{g}) \mathrm{SIN}-1 \mathrm{dose}$. SIN-1 treatment caused dose-dependent augmentation of rPO GnRH-1 and Vglut2 protein content in FD-exposed E-300 rats, thereby normalizing the latter profile. Results show that FD imposes a NO-reversible negative tonus on rPO GnRH-I and Vglut2 protein, but not mRNA expression.

AVPV KiSS1 and DMN RFRP-3 neurons respectively stimulate or inhibit the LH surge via rPO projections [Wu et al., 2009; Lehman et al., 2013; Yip et al., 2015]. Experiment 2 
investigated the prospect of FD-driven nitrergic regulation of gene and/or gene product expression in these cell groups. Figure 5 illustrates effects of SIN-1 on FD-associated patterns of AVPV KiSS1 mRNA (Panel A) and kisspeptin protein (Panel B) and DMN RFRP-3 mRNA (Panel C) and protein (Panel D) expression in E-300 rats. AVPV KiSS1 gene expression was markedly suppressed due to $\mathrm{FD}$, whereas corresponding kisspeptin protein levels were resistant to this metabolic stressor. Both SIN-1 dosages significantly increased KiSS1 gene transcription relative to both $\mathrm{FF} / \mathrm{V}_{\mathrm{LV}}$ and $\mathrm{FD} / \mathrm{V}_{\mathrm{LV}}$ groups. However, AVPV kisspeptin protein content was respectively elevated or not different in FD/S(100) $\mathrm{LV}$ and FD/S(200) $)_{\mathrm{LV}}$ groups compared to FD/ $\mathrm{V}_{\mathrm{LV}}$. FD stimulation of DMN RFRP-3 mRNA and protein expression was attenuated at each SIN-1 dosage. Outcomes implicate NO downregulation in FD augmentation of DMN RFRP-3 gene and gene product expression.

ARH tissue obtained from E-300 animals in Experiment 2 was similarly evaluated for NO involvement in reproduction-relevant neurotransmitter mRNA and protein responses to FD. FD regulation of KiSS1, NPY, and POMC gene and gene product expression in E-300 animals, with or without coincident SIN-1 treatment, is illustrated in Figure 6. Kisspeptin protein but not KiSS1 mRNA was reduced by $\mathrm{FD}\left[\mathrm{FD} / \mathrm{V}_{\mathrm{LV}}\right.$ versus $\left.\mathrm{FF} / \mathrm{V}_{\mathrm{LV}}\right]$; neither profile was affected by SIN-1 administration (Panels A and B). NPY (Panels C and D), but not POMC (Panels E and F) protein was elevated in FD versus FF groups; neither transcript was altered by FD. SIN-1 treatment normalized NPY protein (at the higher dose level), but not mRNA expression, and stimulated POMC gene (100 and $200 \mu \mathrm{g}$ doses) and protein (200 $\mu \mathrm{g}$ dosage) levels. Data show that FD regulates ARH NPY protein, but not gene expression, via NO-dependent mechanisms.

Data in Figure 7 depict effects of SIN-1 administration on pituitary LH secretion in FDexposed E-300 animals. Results show that FD caused a significant decline in hormone output, and that this inhibitory response was reversed by treatment with the lower, but not higher dose of SIN-1.

\section{Discussion}

Metabolic constraint of female reproduction ensures that this lengthy, energy-costly function proceeds only when sufficiency energy is available to ensure successful completion. This study examined the premise that distinctive estrous cycle-associated patterns of E release, embodying negative- versus positive-feedback signals to the reproductive neuroendocrine axis, differentially regulate GnRH-LH sensitivity to short-interval FD. Current data show that in the presence of estrous cycle peak (but not nadir) E levels, FD caused hindbrain AMPK-mediated diminution of rPO nNOS and GnRH-1 proteins, alongside decreased pituitary LH secretion. FD caused divergent Cc-reversible adjustments in preoptic NE accumulation in high- versus low-E - dosed rats, as well as diminished hindbrain AMPKindependent activity in select hypothalamic structures in the latter group. Results suggest that E positive-feedback activation of the GnRH-LH axis is associated with acquired sensitivity to hindbrain metabolic sensory input during FD. E stimulus strength likely establishes forebrain substrates of FD-initiated NE input as well as directionality of NE signaling in those target sites. Observations that the NO donor SIN-1 reverses FD repression of GnRH and several upstream regulatory neuron populations imply that NO is a critical 
coordinating element in neural pathways that impose metabolic restriction of reproductive neuroendocrine function.

The present study addressed the theory that female rat forebrain NE activity may vary in a site-specific manner in response to FD according to estrous cycle stage-specific patterns of $\mathrm{E}$ secretion. Data show that FD decreased NE accumulation throughout the preoptic area and hypothalamus in low-E - dosed rats, but amplified NE activity in preoptic loci in the high-E group. Hindbrain AMPK-driven FD NE signaling was focused to reproduction-significant preoptic loci in both $\mathrm{E}$ dosage groups, but numbers of targeted structures and direction of $\mathrm{NE}$ accumulation in those sites depended upon $\mathrm{E}$ concentration. Intra-CV4 Cc administration normalized rPO NE activity in E-30 (reversal of FD inhibition) and -300 animals (reversal of FD stimulation), as well as NE accumulation in the AVPV and MPN in the latter group. $\mathrm{E}$ is thus a critical determinant of neural location and mode (positive versus negative) of FD-propelled NE activity. To date, the preoptic area has been subject to little scrutiny regarding potential involvement in metabolic homeostasis. Current results emphasize the need to clarify preoptic participation in coordinated corrective responses to metabolic stress, including characterization of local targets and functional sequelae (including counteractive autonomic, neuroendocrine, and/or behavioral outflow) of FDdriven NE signals to the rPO, AVPV, and MPN. Additional research is also necessary to discern if $\mathrm{E}$ dose-dependent diminution (low-E dose) versus augmentation (high-E dose) of NE activity in those sites involves different noradrenergic cell sources or if divergent signals reflect $\mathrm{E}$ dose-dependent control of local NE production and release from a single set of afferent neurons. It is unclear if disparities involving FD-driven NE signaling to hypothalamic metabolic structures involve high E dose 'silencing' of noradrenergic projections to those loci by inhibition of local $\mathrm{NE}$ axon firing or equivalent augmentation of rates of $\mathrm{NE}$ synthesis, degradation, and release, resulting in no net change in tissue $\mathrm{NE}$ content. No Cc effect on FD NE input to the hypothalamus of low-E - dosed animals may reflect activation of non-metabolic-sensory caudal hindbrain noradrenergic neurons or, instead, AMPK-expressing noradrenergic neurons situated outside diffusion range of the CV4.

Current results demonstrate that peak estrous cycle E levels render the GnRH-LH axis susceptible to inhibitory hindbrain metabolic cues. FF E-300 animals exhibited elevated baseline $\mathrm{rPO}$ AMPK activity relative to FF E-30. Although FD recruited hindbrain AMPK control of this rPO sensor in both E-300 and E-30, rPO pAMPK content did not differ between FF versus FD E-300 animals. These outcomes may reflect maximal activation of rPO AMPK by E positive-feedback despite uninterrupted feeding, as whole-body energy state becomes more negative as E secretion rises during proestrus [Giles et al., 2010], with the upshot that FD may have minimal capability to augment sensor activity further. An alternative (albeit less likely) explanation is that hindbrain augmentation of rPO pAMPK expression in FD-exposed E-300 rats may be offset by simultaneous cues for sensor deactivation. rPO GnRH-1 protein content was greater in FF E-300 versus E-30 rats, and was subject to Cc-reversible inhibition by FD, alongside reductions in LH secretion, in the former group. Because GnRH-1 profiles were refractory to FD in lowE animals despite elevated rPO pAMPK activity, this sensor may likely regulate non-reproductive responses to this metabolic stress when E secretion is at nadir. Previous studies showed that $r \mathrm{PO} \mathrm{GnRH}$ 
neurons express AMPK [Ibrahim and Briski, 2014; Shrestha et al., 2014]. Ongoing work aims to determine if, during peak E release, the GnRH-based sensor is selectively activated by FD relative to the rPO at-large, and whether such augmentation is causally related to down-regulated GnRH-I protein expression owing to FD. Additional effort will also examine whether hindbrain AMPK regulation of rPO pAMPK and GnRH-I expression is mediated by down- versus up-regulated NE signals in corresponding E-30 and E-300 animals.

The neurotransmitters $\gamma$-amino-butyric acid (GABA) and nitric oxide (NO) act directly to correspondingly inhibit [Wuttke et al., 1996; Han et al., 2002, 2004] or stimulate [Bhat et al., 1998; Dhandapani and Brann, 2000] GnRH neurons [Bhat et al., 1994; Christian and Moenter, 2010]. Glucoprivation augments rPO GABA neurotransmission [Singh and Briski, 2004] and enhances transcriptional activation of GABA- and nitrergic neurons in that location [Briski and Sylvester, 1999; Briski and Singh, 2008]. Experiment 1 therefore investigated the hypothesis that FD causes Cc-reversible changes in rPO expression of the marker biosynthetic enzymes $\mathrm{GAD}_{65 / 67}$ and nNOS in the presence of nadir and/or peak plasma E. Data reveal that while $\mathrm{rPO}_{\mathrm{GAD}} 65 / 67$ protein levels were refractory to $\mathrm{FD}$ irrespective of $\mathrm{E}$ dose, $\mathrm{rPO}$ nNOS content declined in FD-exposed E-300 animals but normalized despite FD by $\mathrm{Cc}$ treatment. These outcomes infer that $\mathrm{PPO}$ nitrergic neurons are downstream recipients of hindbrain AMPK signaling during FD stress. NE control of PVH magnocellular nerve cell nNOS has been reported [Grange-Messent $\mathrm{V}$ et al., 2004]; our premise that $\mathrm{rPO}$ nNOS may subject to similar control merits investigation. Observations here of augmented baseline nNOS content in FF E-300 versus FF E-30 groups align with proof of NO involvement in steroid positive-feedback induction of the LH surge [Bonavera et al., 1993; Rettori et al., 1994; Kohsaka et al., 1999]. A principle aim of Experiment 2 was to verify whether the parallel fall in $\mathrm{PPO}$ nNOS and GnRH-I protein expression in FDexposed E-300 rats signifies a causal relationship. Data showing SIN-1 augmentation of GnRH-I expression and LH profiles bolster this view, as GnRH-1 mRNA and protein profiles and plasma LH concentrations were greater in SIN-1- versus V-injected FD-exposed E-300 rats. Glutamate is a requisite stimulatory signal for preovulatory LH release [Brann and Mahesh, 1997; Dhanapani and Brann, 2000], acting directly [Christian and Moenter, 2010] and indirectly, via activation of NO release [Brann et al., 1997; Ganapathy et al., 1998], to stimulate GnRH output. GnRH neurons reside in close proximity to large numbers of Vglut2-expressing glutaminergic neurons [Ziegler et al., 2002; Lin et al., 2003]. Current data show that FD provokes SIN-1 - reversible diminution of rPO Vglut2 protein expression, which implies that NO deficiency may down-regulate this key excitatory input to GnRH neurons [Figure 8]. The present studies do not clarify whether glutaminergic neurons are directly controlled by NO during FD, or if NO may indirectly suppress rPO glutamate transmission via diminished kisspeptin.

AVPV and ARH kisspeptinergic neurons are critical mediators of corresponding E positiveand negative-feedback cues to the GnRH-LH axis [Popa et al., 2008]. Kisspeptin stimulates preoptic GnRH, nitrergic, and glutaminergic neurons via GPR54 receptor signaling [Irwig et al., 2004; Messager et al., 2005; Pielecka-Fortuna and Moenter, 2010; Hanchate et al., 2012]. As Experiment 1 identified the AVPV, but not ARH as a target of FD-driven NE cues in E-300 animals, we examined the premise that kisspeptin yield in the former site may be regulated by FD. As immunoblots disclosed a trend (albeit insignificant) toward decreased 
protein in E-300/FD versus E-300/FF groups, we next addressed the premise in Experiment 2 that KiSS1 neurons in the former, but not latter site may exhibit transcriptional reactivity to that metabolic challenge. Outcomes of Experiment 2 document FD-associated decrements in AVPV KiSS1 gene (statistically significant) and protein (statistically insignificant) expression in E-300 animals, as well as notable suppression of ARH kisspeptin protein content. These results align with earlier reports that 48 hour fasting suppresses AVPV (but not ARH) KiSS-1 gene expression in male rats [Kalamatianos et al., 2008]. Moreover, data here show that SIN-1 reversed FD repression of AVPV KiSS1 mRNA and augmented kisspeptin protein levels, but did not modify ARH KiSS1 gene or protein expression. These outcomes implicate NO in AVPV kisspeptinergic cell reactivity to FD; however, it is not known if this nitrergic control involves direct or indirect signaling. It remains unclear if AVPV and/or ARH KiSS1 neurons mediate FD effects on positive-feedback patterns of LH release. ARH kisspeptin/neurokinin B/dynorphin (KNDy) neurons reportedly regulate the LH surge via dynorphin input to the AVPV [Helena et al., 2015]. Present outcomes thus raise the prospect that ARH KNDy cells may function in hindbrain AMPK/NE-independent pathways that curb GnRH during FD.

AVPV KiSS1- and DMN RFRP-3-expressing neurons act in response to circadian cues to respectively stimulate or inhibit the E positive-feedback - induced LH surge [Khan and Kauffman, 2002]. RFRP-3 neurons reside exclusively in the DMN [Kriegsfeld et al., 2006] and provide direct innervation to preoptic GnRH neurons [Wu et al., 2009; Rizwan et al., 2012]. Elevated E inhibits RFRP-3 transmission, thereby dampening inhibition of GnRH [Gibson et al., 2008]. Data forthcoming from Experiment 1 showed that the DMN is the sole hypothalamic target of hindbrain AMPK-controlled NE input in FD-exposed E-300 rats. An objective of Experiment 2 was thus to evaluate sensitivity of DMN RFRP-3 to FD. Results indicate that RFRP-3 mRNA and protein levels are both significantly augmented by FD, and that these responses were prevented by SIN-1. Conjecture that hindbrain AMPK-impelled DMN NE activity regulates RFRP-3 via NO-dependent mechanisms will require experimental validation. As nitrergic nerve cell bodies are absent from the DMN [Bhat et al., 1995], NO regulation of RFRP-3 transmission may involve local release of this gaseous transmitter from axons derived elsewhere in the forebrain or, alternatively, NO activity at extra-DMN substrates that in turn innervate the RFRPergic population.

ARH NPY is obligatory for E positive-feedback initiation of the LH surge [Kalra and Crowley, 1992], while POMC peptide products $\beta$-endorphin ( $\beta$-END) and a-melanocytestimulating hormone (MSH) respectively inhibit or stimulate LH release [Kalra, 1985; Murray et al., 2000]. NPY and POMC gene transcripts or products are sensitive to FD of 24 hours or greater duration [Señarís et al., 2011; Sainsbury and Zhang, 2010; Jovanovic et al., 2010]. Previous work showed that in E-30 animals, hindbrain AMPK exerts an inhibitory versus stimulatory influence on ARH NPY and POMC protein expression, respectively, during FD [Alenazi et al., 2016]. Data here from E-300 rats indicate that FD-associated augmentation of NPY protein (but not mRNA) is reversible by SIN-1. Further effort is required to determine the neuroanatomical location of nitrergic neurons that mediate this impact of FD. There is also a need to examine whether such amplification of NPY expression is mediated by hindbrain AMPK through NE-independent mechanisms, and if intensified NPYergic input offsets stimuli that inhibit LH release. Repression of inhibitory 
endorphinergic input to the GnRH-LH axis enables the LH surge. Here, FD imposed for 18 hours did not alter ARH POMC mRNA or protein content, suggesting that the duration of FD may be a critical determinant of POMC reactivity to this metabolic stress. Evidence here for high dose enhancement of POMC expression by SIN-1 raises the possibility that $\beta$-END suppressive action may be increased, thereby overshadowing stimulatory mechanisms that prevail at lower dosages of SIN-1

In summary, the present project yields novel proof of differential reproductive neuroendocrine sensitivity to short-term FD related to female rat estrous cycle patterns of $\mathrm{E}$ secretion. Data show that in the presence of peak (proestrus-like) circulating E levels, FD elicits hindbrain AMPK-dependent suppression of rPO nNOS and GnRH-1 protein expression and pituitary LH release. Results thus imply that E positive-feedback activation of the GnRH-LH axis heightens its sensitivity to hindbrain metabolic sensory input during FD. E stimulus strength likely establishes forebrain substrates of FD-initiated NE input as well as directionality of NE signaling in those target sites. Observations that the NO donor SIN-1 reverses FD repression of GnRH and several upstream regulatory neuron populations imply that NO may act simultaneously via preoptic and DMN NE-dependent mechanisms to curb pre-ovulatory LH secretion during metabolic stress [Figure 8].

\section{Abbreviations}

$\begin{array}{ll}\text { AMPK } & \text { adenosine } 5^{\prime} \text {-monophosphate-activated protein kinase } \\ \text { ARH } & \text { arcuate hypothalamic nucleus } \\ \text { AVPV } & \text { anteroventral periventricular nucleus } \\ \text { Cc } & \text { Compound c } \\ \text { CV4 } & \text { caudal fourth ventricle } \\ \text { DMN } & \text { dorsomedial hypothalamic nucleus } \\ \text { DMSO } & \text { dimethyl sulfoxide } \\ \text { E } & \text { estradiol } \\ \text { FD } & \text { food-deprivation } \\ \text { FF } & \text { full-fed } \\ \text { KiSS1 } & \text { metastasis-suppressor KiSS-1 } \\ \text { GABA } & \gamma \text {-amino-butyric acid } \\ \text { GnRH } & \text { gonadotropin-releasing hormone } \\ \text { HPG } & \text { hypothalamic-pituitary-gonadal } \\ \text { LH } & \text { luteinizing hormone } \\ \text { LHA } & \text { lateral hypothalamic area } \\ \end{array}$




$\begin{array}{ll}\text { LV } & \text { left lateral ventricle } \\ \text { MPN } & \text { medial preoptic nucleus } \\ \text { NE } & \text { norepinephrine } \\ \text { NO } & \text { nitric oxide } \\ \text { NNOS } & \text { neuronal nitric oxide synthase } \\ \text { NPY } & \text { neuropeptide Y } \\ \text { OVX } & \text { ovariectomy } \\ \text { O.D. } & \text { optical density } \\ \text { pAMPK } & \text { phospho-AMPK } \\ \text { POMC } & \text { proopiomelanocortin } \\ \text { PVN } & \text { paraventricular hypothalamic nucleus } \\ \text { SIN-1 } & \text { 3-morpholinosydnonimine } \\ \text { RFRP-3 } & \text { RFamide-related peptide-3 } \\ \text { RPO } & \text { rostral preoptic area } \\ \text { Vglut2 } & \text { vesicular glutamate transporter-2 } \\ \text { VMN } & \text { ventromedial hypothalamic nucleus }\end{array}$

\section{References}

Adler BA, Johnson MD, Lynch CO, Crowley WR. Evidence that norepinephrine and epinephrine systems mediate the stimulatory effects of ovarian hormones on luteinizing hormone and luteinizing hormone-releasing hormone. Endocrinology. 1983; 113:1431-1438. [PubMed: 6352246]

Alenazi FSH, Ibrahim BA, Alhamami H, Shakya M, Briski KP. Role of estradiol in intrinsic hindbrain AMPK regulation of hypothalamic AMPK, metabolic neuropeptide, and norepinephrine activity and food intake in the female rat. Neuroscience. 2016; 314:35-46. [PubMed: 26628404]

Alenazi FSH, Ibrahim BA, Briski KP. Estradiol regulates effects of hindbrain AICAR administration on hypothalamic AMPK activity and metabolic neurotransmitter mRNA and protein expression. J Neurosci Res. 2014; 93:651-659. [PubMed: 25476093]

Bhat GK1, Mahesh VB, Lamar CA, Ping L, Aguan K, Brann DW. Histochemical localization of nitric oxide neurons in the hypothalamus: association with gonadotropin-releasing hormone neurons and co-localization with N-methyl-D-aspartate receptors. Neuroendocrinology. 1995; 62:187-197. [PubMed: 8584118]

Bhat GK, Mahesh VB, Ping L, Chorich L, Wiedmeier VT, Brann DW. Opioid-glutamate-nitric oxide connection in the regulation of luteinizing hormone secretion in the rat. Endocrinology. 1998; 139:955-960. [PubMed: 9492025]

Bohler HC, Tracer H, Merriam GR, Petersen SL. Changes in proopiomelanocortin messenger ribonucleic acid levels in the rostral periarcuate region of the female rat during the estrous cycle. Endocrinology. 1991; 128:1265-1269. [PubMed: 1999146]

Bonavera JJ, Kalra PS, Kalra SP. Evidence that nitric oxide may mediate the ovarian steroid-induced luteinizing hormone surge: involvement of excitatory amino acids. Endocrinology. 1993:2481-2487. [PubMed: 8243268] 
Brann DW, Bhat GK, Lamar CA, Mahesh VB. Gaseous transmitters and neuroendocrine regulation. Neuroendocrinology. 1997; 65:385-395. [PubMed: 9208400]

Brann DW, Mahesh VB. Excitatory amino acids: evidence for a role in the control of reproduction and anterior pituitary hormone secretion. Endroc Rev. 1997; 14:507-538.

Briski KP. Pharmacological manipulation of central nitric oxide/guanylate cyclase activity alters Fos expression by rat hypothalamic vasopressinergic neurons during acute glucose deprivation. J Chem Neuroanat. 1999; 17:13-19. [PubMed: 10569236]

Briski KP, Alenazi FSH, Shakya M, Sylvester PW. Estradiol regulates hindbrain A2 noradrenergic neuron adenosine $5^{\prime}$-monophosphate-activated protein kinase (AMPK) activation, upstream kinase/phosphatase protein expression, and receptivity to hormone and fuel reporters of short-term food deprivation in the ovariectomized female rat. J Neurosci Res. 2016; 95:1427-1437. [PubMed: 27618227]

Briski KP, Marshall ES, Sylvester PW. Effects of estradiol on glucoprivic transactivation of catecholaminergic neurons in the female rat caudal brainstem. Neuroendocrinology. 2001; 73:369377. [PubMed: 11408778]

Briski KP, Shrestha PK. Hindbrain estrogen receptor-beta antagonism normalizes reproductive and counter-regulatory hormone secretion in hypoglycemic steroid-primed ovariectomized female rats. Neuroscience. 2016; 331:62-71. [PubMed: 27316550]

Briski KP, Singh SR. Hindbrain neuroglucopenia elicits site-specific transcriptional activation of glutamate decarboxylase immunopositive neurons in rat septopreoptic area. Neuroendocrinology. 2008; 87(2):113-120. [PubMed: 17934249]

Briski KP, Sylvester PW. Effects of the glucose antimetabolite, 2-deoxy-D-glucose (2-DG), on the LH surge and Fos expression by preoptic GnRH neurons in ovariectomized, steroid-primed rats. J Neuroendocrinol. 1998; 10:769-776. [PubMed: 9792328]

Briski KP, Sylvester PW. Site-specific induction of Fos immunoreactivity in preoptic and hypothalamic NADPH-positive neurons during glucoprivation. Neuroendocrinology. 1999; 69:181-190. [PubMed: 10087450]

Butcher RL, Collins WE, Fugo NW. Plasma concentrations of LH, FSH, progesterone, and estradiol-17beta throughout the 4-day estrous cycle of the rat. Endocrinology. 1974; 94:17041708. [PubMed: 4857496]

Cameron JL, Nosbisch C. Suppression of pulsatile luteinizing hormone and testosterone secretion during short term food restriction in the adult male rhesus monkey (Macaca mulatta). Endocrinology. 1991; 128:1532-1540. [PubMed: 1999171]

Christian CA, Moenter SM. The neurobiology of preovulatory and estradiol-induced gonadotropinreleasing hormone surges. Endroc Rev. 2010; 31:544-577.

Colella AD, Chegenii N, Tea MN, Gibbins IL, Williams KA, Chataway TK. Comparison of Stain-Free gels with traditional immunoblot loading control methodology. Anal Biochem. 2012; 430:108110. [PubMed: 22929699]

Demling J, Fuchs E, Baumert M, Wuttke W. Preoptic catecholamine, GABA, and glutamate release in ovariectomized and ovariectomized estrogen-primed rats utilizing a push-pull cannula technique. Neuroendocrinology. 1985; 41:212-218. [PubMed: 2864651]

Dhandapani KM, Brann DW. The role of glutamate and nitric oxide in the reproductive neuroendocrine system. Biochem Cell Biol. 2000; 78:165-179. [PubMed: 10949072]

Gibson EM, Humber SA, Jain S, Williams WP, Zhao S, Bentley GE, Tsutsui K, Kriegsfeld LJ. Alterationa in RFamide-related peptide expression are coordinated with the preovulatory luteinizing hormone surge. Endocrinology. 2008; 149:4958-4969. [PubMed: 18566114]

Gilda JE, Gomes AV. Stain-Free total protein staining is a superior loading control to $\beta$-actin for Western blots. Anal Biochem. 2013; 440:186-188. [PubMed: 23747530]

Gilda JE, Gomes AV. Western blotting using in-gel protein labeling as a normalization control: stainfree technology. Methods Mol Biol. 2015; 1295:381-391. [PubMed: 25820735]

Giles ED, Jackman MR, Johnson GC, Schedin PJ, Houser JL, MacLean PS. Effect of the estrous cycle and surgical ovariectomy on energy balance, fuel utilization, and physical activity in lean and obese female rats. Amer J Physiol Regul Integr Comp Physiol. 2010; 299:R1634-R1642. [PubMed: 20926768] 
Goodman RL. A quantitative analysis of the physiological role of estradiol and progesterone in the control of tonic and surge secretion of luteinizing hormone in the rat. Endocrinology. 1978; 102:142-150. [PubMed: 570477]

Grange-Messent V, Raison D, Dugas B, Calas A. Noradrenaline up-regulates the neuronal and the inducible nitric oxide synthase isoforms in magnocellular neurons of rat brain slices. J Neurosci Res. 2004; 78:683-690. [PubMed: 15495217]

Gujar AD, Ibrahim BA, Tamrakar P, Briski KP. Hypoglycemia differentially regulates hypothalamic glucoregulatory neurotransmitter gene and protein expression: Role of caudal dorsomedial hindbrain catecholaminergic input. Neuropeptides. 2013; 47:139-147. [PubMed: 23490004]

Gürtler A, Kunz N, Gomolka M, Hornhardt S, Friedl AA, McDonald K, Kohn JE, Posch A. Stain-Free technology as a normalization tool in Western blot analysis. Anal Biochem. 2013; 433:105-111. [PubMed: 23085117]

Han SK, Abraham IM, Herbison AE. Effect of GABA on GnRH neurons switches from depolarization to hyperpolarization at puberty in the female mouse. Endocrinology. 2002; 143:1459-1466. [PubMed: 11897704]

Han SK, Todman MG, Herbison AE. Endogenous GABA release inhibits the firing of adult gonadotropin-releasing hormone neurons. Endocrinology. 2004; 145:495-499. [PubMed: 14617578]

Hanchate NK, Parkash J, Bellefontaine N, Mazur D, Colledge WH, d'Anglemont de Tassigny X, Prevot V. Kisspeptin-GPR54 signaling in mouse NO-synthesizing neurons participates in the hypothalamic control of ovulation. J Neurosci. 2012; 32:932-945. [PubMed: 22262891]

Helena CV, Toporikova N, Kalil B, Stathopoulos AM, Pogrebna VV, Carolino RO, Anselmo-Franci JA, Bertram R. KNDy neurons modulate the magnitude of the steroid-induced luteinizing hormone surges in ovariectomized rats. Endocrinology. 2015; 156:4200-4213. [PubMed: 26302111]

Ibrahim BA, Briski KP. Role of dorsal vagal complex A2 noradrenergic neurons in hindbrain glucoprivic inhibition of the luteinizing hormone surge in the steroid-primed ovariectomized female rat: Effects of 5-thioglucose on A2 functional biomarker and AMPK activity. Neuroscience. 2014; 269:199-214. [PubMed: 24631866]

Ibrahim BA, Briski KP. Deferred feeding and body weight responses to short-term interruption of fuel acquisition: Impact of estradiol. Horm Metab Res. 2015; 47:611-621. [PubMed: 25230326]

Ibrahim BA, Tamrakar P, Gujar AD, Koshy Cherian A, Briski KP. Caudal fourth ventricular administration of the AMPK activator 5-aminoimiazole-4-carboxamide-riboside regulates glucose and counterregulatory hormone profiles, dorsal vagal complex metabolosensory neuron function, and hypothalamic Fos expression. J Neurosci Res. 2013; 91:1226-1238. [PubMed: 23825033]

Irwig MS, Fraley GS, Smith JT, Acohido BV, Popa SM, Cunningham MJ, Gottsch ML, Clifton DK, Steiner RA. Kisspeptin activation of gonadotropin releasing hormone neurons and regulation of KiSS-1 mRNA in the male rat. Neuroendocrinology. 2004; 80:264-272. [PubMed: 15665556]

Jovanovic Z, Tung YC, Lam BY, O’Rahilly S, Yeo GS. Identification of the global transcriptomic response of the hypothalamic arcuate nucleus to fasting and leptin. J Neuroendocrinol. 2010; 22:915-925. [PubMed: 20553370]

Kalamatianos T, Grimshaw SE, Poorun R, Hahn JD, Coen CW. Fasting reduces KiSS-1 expression in the anteroventral periventricular nucleus (AVPV): effects of fasting on the expression of KiSS-1 and neuropeptide Y in the AVPV or arcuate nucleus of female rats. J Neuroendocrinol. 2008; 20:1089-1097. [PubMed: 18573184]

Kalra SP, Crowley WR. Neuropeptide Y: a novel neuroendocrine peptide in the control of pituitary hormone secretion, and its relation to luteinizing hormone. Front Neuroendocrinol. 1992; 13:1-46. [PubMed: 1361458]

Kalra SP. Neural circuits involved in the control of LHRH secretion: a model for estrous cycleregulation. J Steroid Biochem. 1985; 23:733-742. [PubMed: 2934578]

Khan AR, Kauffman AS. The role of kisspeptin and RFamide-related peptide-3 neurones in the circadian-timed preovulatory luteinising hormone surge. J Neuroendocrinol. 2012; 24:131-143. [PubMed: 21592236]

Klingerman, CM., Williams, WP., Simberlund, J., Brahme, N., Prasad, A., Schneider, JE., Kriegsfeld, LJ. Food restriction-induced changes in gonadotropin-inhibiting hormone cells are associated with 
changes in sexual motivation and food hoarding, but not sexual performance and food intake. Front Endocrinol. 2011. https://doi.org/10.3389/fendo.2011.00101

Kohsaka A, Watanobe H, Kakizaki Y, Suda T. A comparative study of the effects of nitric oxide and carbon monoxide on the in vivo release of gonadotropin-releasing hormone and neuropeptide $Y$ from rat hypothalamus during the estradiol-induced luteinizing hormone surge: estimation by push-pull perfusion. Neuroendocrinology. 1999; 69:245-253. [PubMed: 10207276]

Lehman MN, Hileman SM, Goodman RL. Neuroanatomy of the kisspeptin signaling system in mammals: comparative and developmental aspects. Adv Exp Med Biol. 2013; 784:27-62. [PubMed: 23550001]

Leon S, Garcia-Galiano D, Ruiz-Pino F, Barroso A, Manfredi-Lozano M, Romero-Ruiz A, Roa J, Vazquez MJ, Gaytan F, Blomenrohr M, van Duin M, Pinilla L, Tena-Sempere M. Physiological roles of gonadotropin-inhibitory hormone signaling in the control of mammalian reproductive axis: Studies in the NPFF1 receptor null mouse. Endocrinology. 2014; 155:2953-2965. [PubMed: 24823392]

Leonhardt S, Shahab M, Luft H, Wuttke W, Jarry H. Reduction of luteinizing hormone secretion induced by long-term feed restriction in male rats is associated with increased expression of GABA-synthesizing enzymes without alterations of GnRH gene expression. J Neuroendocrinol. 1999; 11:613-619. [PubMed: 10447799]

Lin W, McKinney K, Liu L, Lakhlani S, Jennes L. Distribution of vesicular glutamate transporter-2 messenger ribonucleic acid and protein in the septum-hypothalamus of the rat. Endocrinology. 2003; 144:662-670. [PubMed: 12538629]

Luque RM, Kineman RD, Tena-Sempere M. Regulation of hypothalamic expression of KiSS-1 and GPR54 genes by metabolic factors: analyses using mouse models and a cell line. Endocrinology. 2007; 148:4601-4611. [PubMed: 17595226]

Messager S, Chatzidaki EE, Ma D, Hendrick AG, Zahn D, Dixon J, Thresher RR, Malinge I, Lomet D, Carlton MB, Colledge WH, Caraty A, Aparicio SA. Kisspeptin directly stimulates gonadotropinreleasing hormone release via G protein-coupled receptor 54. Proc Natl Acad Sci. 2005; 102:1761-1766. [PubMed: 15665093]

Murray JF, Adan RA, Walker R, Baker BI, Thody AJ, Nijenhuis WA, Yukitake J, Wilson CA. Melaninconcentrating hormone, melanocortin receptors and regulation of luteinizing hormone release. $\mathrm{J}$ Neuroendocrinol. 2000; 12:217-223. [PubMed: 10718917]

Nagatani S, Bucholtz DC, Murahashi K, Estacio MA, Tsukamura H, Foster DL, Maeda KI. Reduction of glucose availability suppresses pulsatile luteinizing hormone release in female and male rats. Endocrinology. 1996; 137:1166-1170. [PubMed: 8625885]

Ohkura S, Tanaka T, Nagatani S, Bucholtz DC, Tsukamura H, Maeda K, Foster DL. Central, but not peripheral, glucose-sensing mechanisms mediate glucoprivic suppression of pulsatile luteinizing hormone secretion in the sheep. Endocrinology. 2000; 141:4472-4480. [PubMed: 11108257]

Oomura Y, Yoshimatsu H. Neural network of glucose monitoring system. J Auton Nerv Syst. 1984; 10:359-372. [PubMed: 6090526]

Pielecka-Fortuna J, Moenter SM. Kisspeptin increases -aminobutyric acidergic and glutaminergic transmission directly to gonadotropin-releasing hormone neurons in an estradiol-dependent manner. Endocrinology. 2010; 151:291-300. [PubMed: 19880809]

Popa SM, Clifton DK, Steiner RA. The role of kisspeptins and GPR54 in the neuroendocrine regulation of reproduction. Annu Rev Physiol. 2008; 70:213-238. [PubMed: 17988212]

Rettori V, Belova N, Dees WL, Nyberg CL, Gimeno N, McCann SM. Role of nitric oxide in the control of luteinizing hormone-releasing hormone release in vivo and in vitro. Proc Natl Acad Sci. 1994; 90:10130-10134.

Rizwan MZ, Poling MC, Corr M, Cornes PA, Augustine RA, Quennell JH, Kauffman AS, Anderson GM. RFamide-related peptide-3 receptor gene expression in GnRH and kisspeptin neurons and GnRH-dependent mechanism of action. Endocrinology. 2012; 153:3770-3779. [PubMed: 22691552]

Sainsbury A, Zhang L. Role of the arcuate nucleus of the hypothalamus in regulation of body weight during energy deficit. Mol Cell Endocrinol. 2010; 316:109-119. [PubMed: 19822185] 
Schreihofer DA, Amico JA, Cameron JL. Reversal of fasting-induced suppression of luteinizing hormone ( $\mathrm{LH})$ secretion in male rhesus monkeys by intragastric nutrient infusion: evidence for rapid stimulation of LH by nutritional signals. Endocrinology. 1993; 132:1890-1897. [PubMed: 8477642]

Señarís RM, Trujillo ML, Navia B, Comes G, Ferrer B, Giralt M, Hidalgo J. Interleukin-6 regulates the expression of hypothalamic neuropeptides involved in body weight in a gender-dependent way. $\mathrm{J}$ Neuroendocrinol. 2011; 23:675-686. [PubMed: 21564350]

Shrestha PK, Tamrakar P, Ibrahim BA, Briski KP. Hindbrain medulla catecholamine cell group involvement in lactate-sensitive hypoglycemia-associated patterns of hypothalamic norepinephrine and epinephrine activity. Neuroscience. 2014; 278:20-30. [PubMed: 25084049]

Singh SR, Briski KP. Septopreoptic mu opioid receptor mediation of hindbrain glucoprivic inhibition of reproductive neuroendocrine function in the female rat. Endocrinology. 2004a; 145:5322-5331. [PubMed: 15308614]

Singh SR, Briski KP. Caudal hindbrain glucoprivation enhances GABA release in discrete septopreoptic structures in the steroid-primed ovariectomized rat brain: Role of mu opioid receptors. Neuroendocrinology. 2004b; 80:201-209. [PubMed: 15591795]

Wade GN, Jones JE. Neuroendocrinology of nutritional infertility. Amer J Physiol. 2004; 287:R1227R1296.

Watanobe H, Schioth HB. Nitric oxide mediates leptin-induced preovulatory luteinizing hormone and prolactin surges in rats. Brain Res. 2001; 923:193-197. [PubMed: 11743988]

Wise PM, Rance N, Barraclough CA. Effects of estradiol and progesterone on catecholamine turnover rates in discrete hypothalamic regions in ovariectomized rats. Endocrinology. 1981; 108:21862193. [PubMed: 6785074]

Wise PM, Scarbrough K, Weiland NG, Larson GH. Diurnal pattern of proopiomelanocortin gene expression in the arcuate nucleus of proestrous, ovariectomized, and steroid-treated rats: a possible role in cyclic luteinizing hormone secretion. Mol Endocrinol. 1990; 4:886-892. [PubMed: 2233745]

Wuttke W, Jarry H, Feleder C, Moguilevsky J, Leonhardt S, Seong JY, Kim K. The neurochemistry of the GnRH pulse generator. Acta Neurobiol Exp. 1996; 56:707-713.

Wu M, Dumalska I, Morozova E, van den Pol AN, Alreja M. Gonadotropin inhibitory hormone $(\mathrm{GnIH})$ innervates, inhibits basal forebrain vGluT2-GnRH neurons via a direct postsynaptic mechanism. J Physiol. 2009; 587:1401-1411. [PubMed: 19204051]

Yip SH, Boehm U, Herbison AE, Campbell RE. Conditional Viral Tract Tracing Delineates the Projections of the Distinct KisspeptinNeuron Populations to Gonadotropin-Releasing Hormone (GnRH) Neurons in the Mouse. Endocrinology. 2015; 156:2582-2594. [PubMed: 25856430]

Yokotani K, Murakami Y, Okuma Y, Osuma Y. Centrally applied nitric oxide donor inhibit vagally evoked rat gastric acid secretion: involvement of sympathetic outflow. Jpn J Pharmacol. 1997; 74:337-340. [PubMed: 9307330]

Ziegler DR, Cullinan WE, Herman JP. Distribution of vesicular glutamate transporter mRNA in rat hypothalamus. J Comp Neurol. 2002; 448:217-229. [PubMed: 12115705] 


\section{Highlights}

- $\quad$ Metabolic cues restrain gonadotropin-releasing hormone $(\mathrm{GnRH})$-luteinizing hormone (LH) output

- $\quad$ Short-term food deprivation (FD) inhibits GnRH/LH when estradiol levels are at estrous cycle peak.

- $\quad$ Hindbrain Compound $\mathrm{C}(\mathrm{Cc})$ delivery reverses FD repression of reproductive neuroendocrine axis

- $\quad$ Cc reverses FD augmentation or suppression of preoptic norepinephrine and nitric oxide synthase

- $\quad$ SIN-1 attenuates FD inhibition of GnRH/LH 

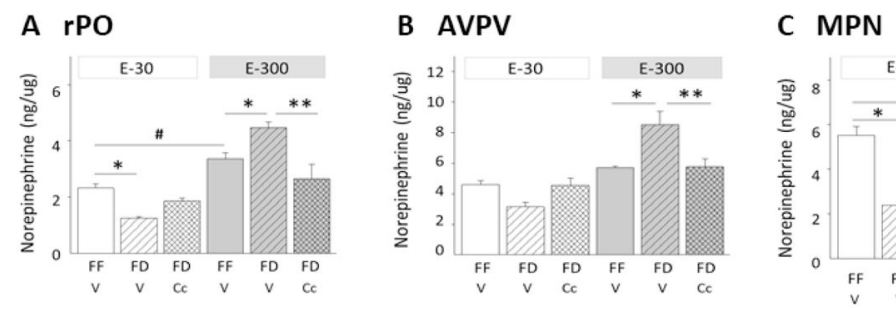

C MPN
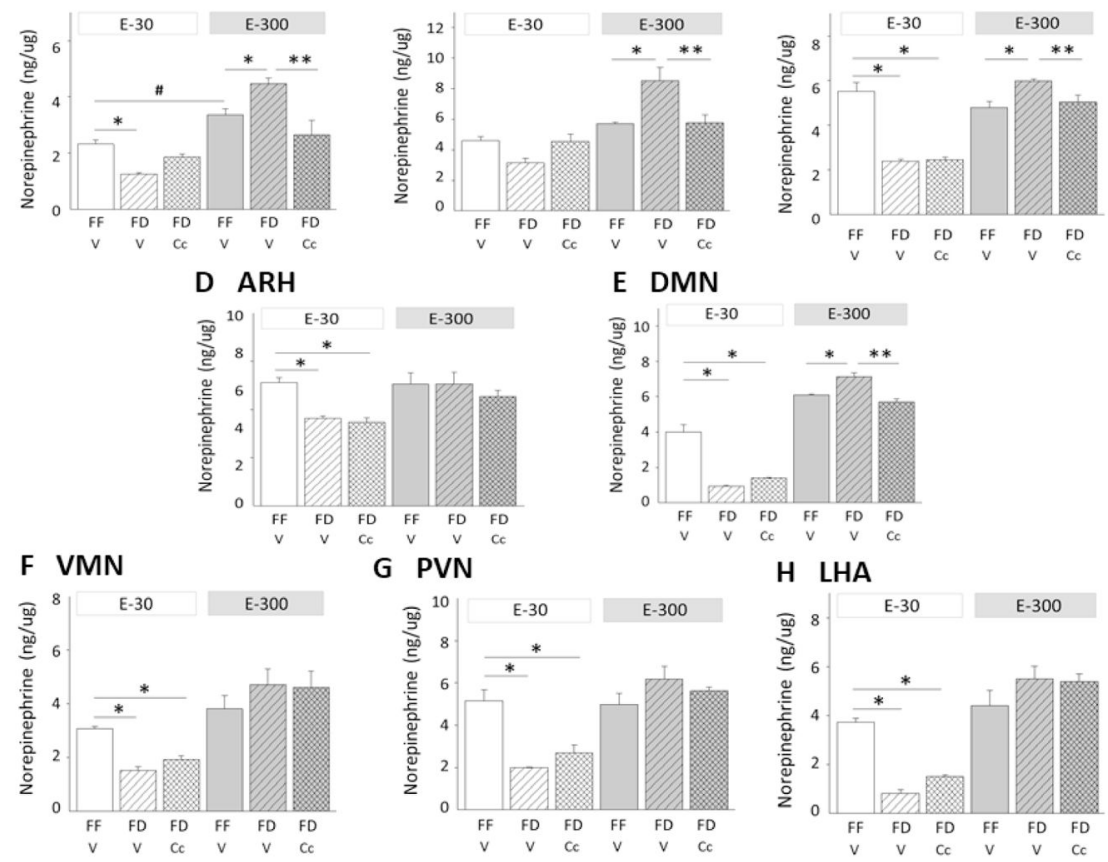

G PVN

H LHA
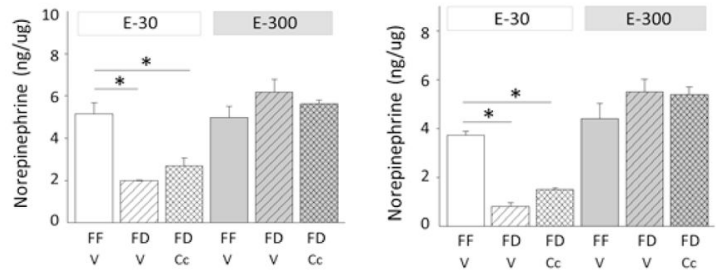

Figure 1. Effects of CV4 Administration of the AMPK Inhibitor Compound C (Cc) on ShortTerm FD-Associated Adjustments in Preoptic/Hypothalamic Norepinephrine (NE) Activity in EImplanted OVX Female Rats

E [30 (E-30) versus $300(\mathrm{E}-300) \mu \mathrm{g} / \mathrm{mL}]$ - implanted OVX rats were exposed to FD or served as full-fed (FF) controls. FF animals were injected into the CV4 with the vehicle dimethyl sulfoxide (DMSO; V) [solid bars], while FD rats received V [diagonal-striped bars] or Cc [5.0 $\mu \mathrm{g} / 2.0 \mu \mathrm{L}$ DMSO; cross-hatched bars] 1 hour prior to sacrifice. Graphs depict mean rostral preoptic area (rPO; Panel A), anteroventral periventricular nucleus (AVPV; Panel B), medial preoptic nucleus (MPN; Panel C), arcuate hypothalamic nucleus (ARH; Panel D), dorsomedial hypothalamic nucleus (DMN; Panel E), ventromedial hypothalamic nucleus (VMN, Panel), paraventricular hypothalamic nucleus (PVN; Panel G), and lateral hypothalamic area (LHA, Panel H) tissue NE content \pm S.E.M. in E-30/FF/V (solid white bars), E-30/FD/V (diagonal-striped white bars), E-30/FD/Cc (cross-hatched white bars), E-300/FF/V (solid grey bars), E-300/FD/V (diagonal-striped grey bars), and E-300/FD/Cc (cross-hatched grey bars) animals ( $\mathrm{n}=4$ /group). ${ }^{*} \mathrm{p}<0.05$ compared to $\mathrm{FF} / \mathrm{V} ; * * \mathrm{p}<0.05$ versus FD/V; \#p<0.05 versus E-30/FF/V. 
A rPO pAMPK

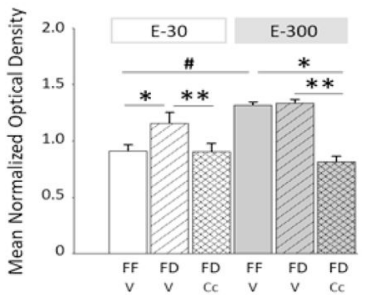

D $\mathrm{rPO} \mathrm{GAD}_{65 / 67}$

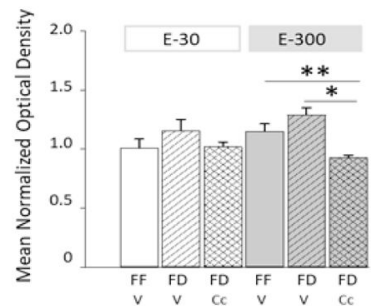

B rPO GnRH-I

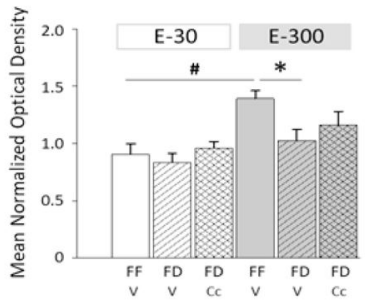

E AVPV Kisspeptin $\quad F$

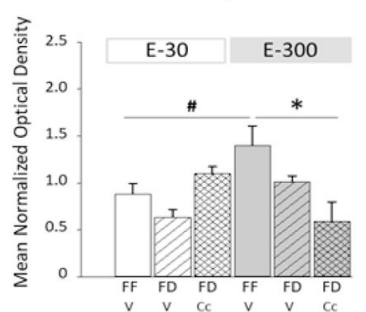

C rPO nNOS

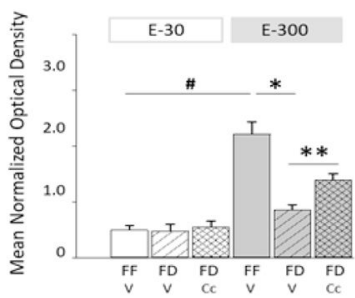

$E-30 \quad E-300$

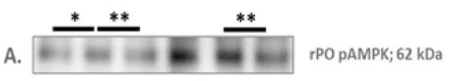

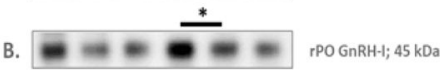

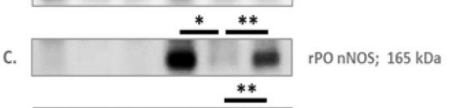

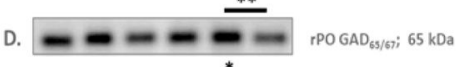

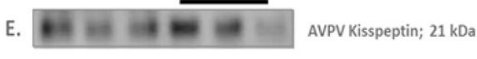

$\mathrm{FF} / \mathrm{V} \mathrm{FD} / \mathrm{N} \mathrm{FD/CC} \mathrm{FF/V} \mathrm{FD/V} \mathrm{FD/CC}$

Figure 2. Hindbrain AMPK Regulation of rPO AMPK Activity and rPO/AVPV ReproductionRegulatory Proteins in FD-Exposed E-Implanted OVX Rats

Panels A-E correspondingly depict mean normalized rPO phospho-AMPK (pAMPK), rPO

GnRH-I, rPO neuronal nitric oxide synthase (nNOS), rPO glutamate decarboxylate $65 / 67$

$\left(\mathrm{GAD}_{65 / 67}\right)$ and AVPV kisspeptin protein optical density measures \pm S.E.M. for FF/V, FD/V, and FD/Cc groups of E-30 or E-300 animals. Panel F shows typical Western blots of rPO pAMPK (Row A), GnRH-I (Row B), nNOS (Row C), GAD 65/67 (Row D), kisspeptin (Row E) and a-tubulin (Row F). ${ }^{*} \mathrm{p}<0.05$ versus FF/V; $* * \mathrm{p}<0.05$ versus $\mathrm{FD} / \mathrm{V}$; \#p<0.05 versus E-30/FF/V. 


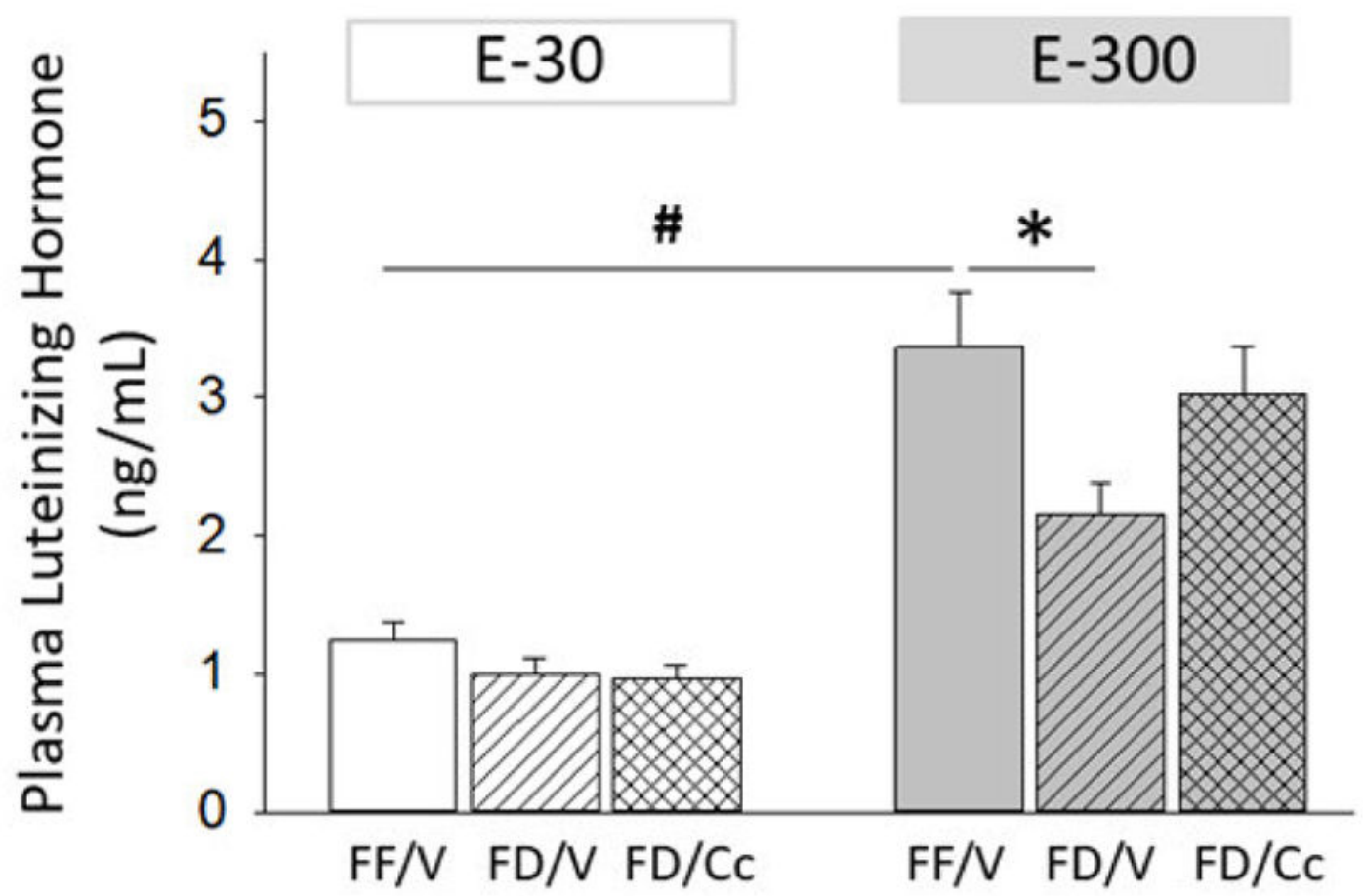

Figure 3. Effects of FD, with or without CV4 Cc Administration, on Pituitary Luteinizing Hormone (LH) Secretion in FD-Exposed E-30 versus E-300 OVX Rats

Bars show mean plasma LH concentrations \pm S.E.M. for FF/V, FD/V, and FD/Cc groups of E-30 and E-300 animals. *p<0.05 compared to FF/V; \#p<0.05 versus E-30/FF/V. 


\section{A rPO GnRH-I mRNA}

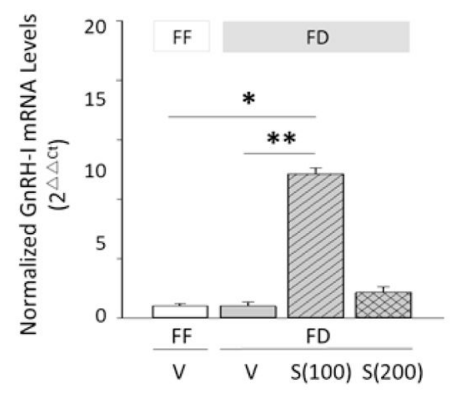

B rPO GnRH-I protein

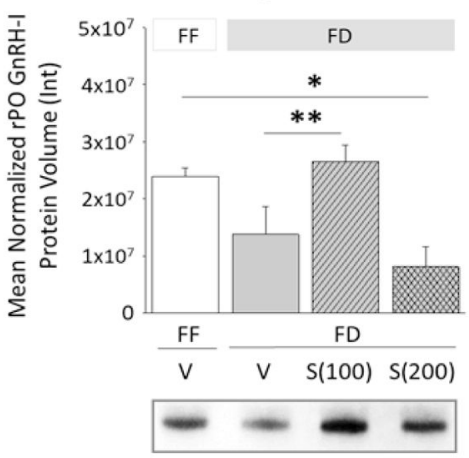

C rPO Vglut2 mRNA

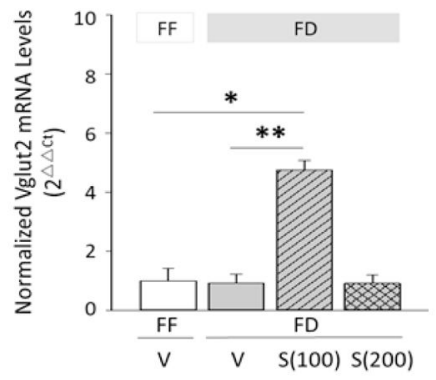

D rPO Vglut2 protein

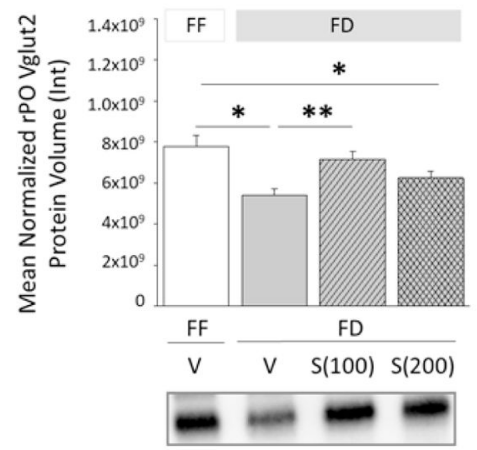

Figure 4. Impact of Lateral Ventricular (LV) Delivery of the Nitric Oxide Donor 3Morpholinosydnonimine (SIN-1) on FD-Associated Patterns of rPO GnRH-1 and Vesicular Glutamate Transporter-2 (Vglut2) Protein Expression in E-Implanted OVX Rats

Mean rPO GnRH-I mRNA (Panel A) and protein (Panel B) and rPO Vglut2 transcript (Panel C) and protein (Panel D) measures \pm S.E.M. are depicted for FF/V, FD/V, FD/S(100), and $\mathrm{FD} / \mathrm{S}$ (200) groups of E-300 rats ( $\mathrm{n}=5$ /group). Graphs presented in Panels B and D are accompanied by representative immunoblots for GnRH-I and Vglut2, respectively. ${ }^{*} \mathrm{p}<0.05$ compared to $\mathrm{FF} / \mathrm{V} ; * * \mathrm{p}<0.05$ versus $\mathrm{FD} / \mathrm{V}$. 
A AVPV KISS1 MRNA

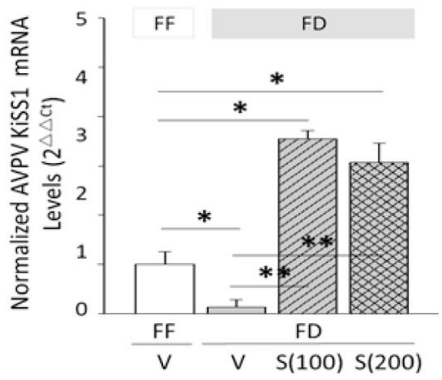

B AVPV Kisspeptin protein

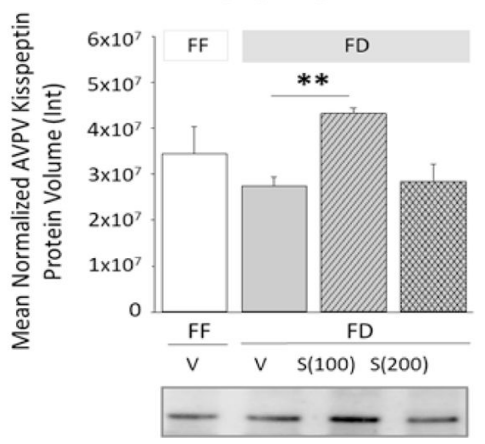

C DMN RFRP MRNA

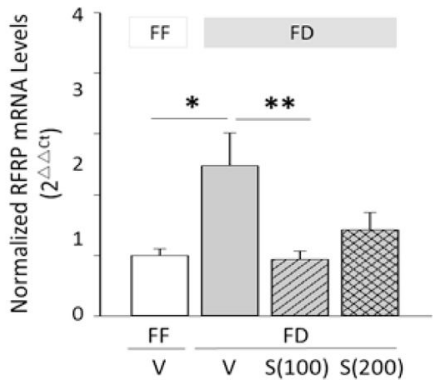

D DMN RFRP-3 protein

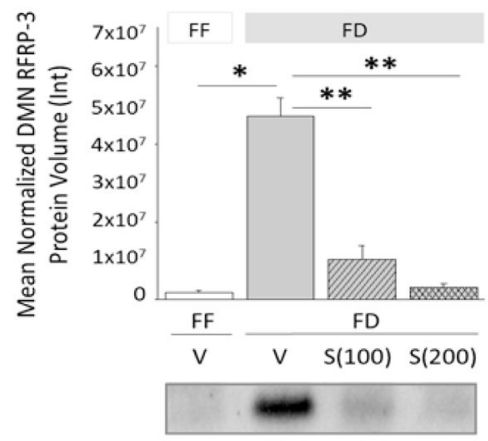

Figure 5. Effects of LV SIN-1 Administration on AVPV Kisspeptinergic and DMN RFRPergic Responses to FD in E-Implanted OVX Rats

Panels A and B correspondingly depict mean AVPV KiSS1 mRNA and kisspeptin protein values \pm S.E.M. for FF/V, FD/V, FD/S(100), and FD/S(200) groups of E-300 animals. Panels $\mathrm{C}$ and D illustrate mean normalized values for DMN RFRP mRNA and RFRP-3 protein content for those groups. Representative kisspeptin and RFRP-3 Western blots are presented in Panels B and D, respectively. *p<0.05 compared to FF/V; **p<0.05 versus FD/V; \#p<0.05 versus E-30/FF/V. 
A ARH KiSS1 mRNA

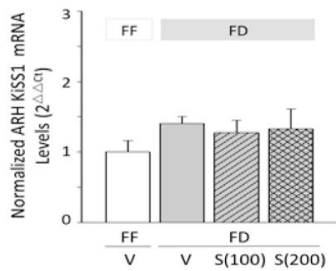

B ARH Kisspeptin protein

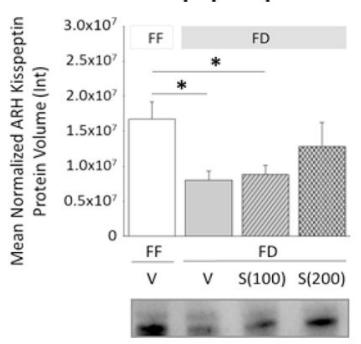

C ARH NPY MRNA

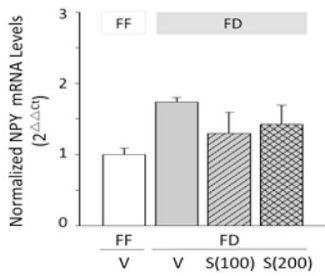

D ARH NPY protein

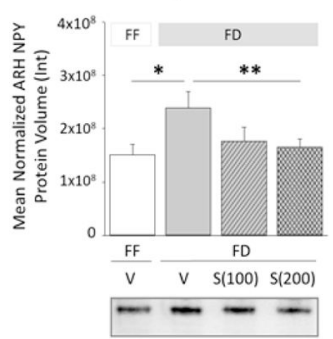

E ARH POMC MRNA

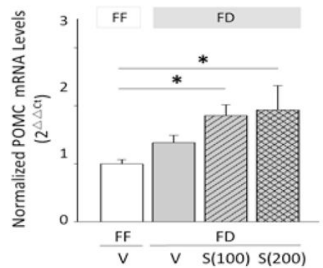

F ARH POMC protein

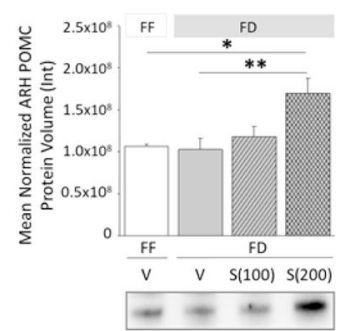

Figure 6. Role of Nitric Oxide in FD-Associated Patterns of ARH Kisspeptin, Neuropeptide Y (NPY), and Pro-opiomelanocortin (POMC) Gene and Protein Expression in E-Implanted OVX Rats

ARH KiSS1 mRNA (Panel A) and kisspeptin protein (Panel B), NPY mRNA (Panel C) and protein (Panel D), and POMC mRNA (Panel E) and protein (Panel F) values \pm S.E.M. are shown for FF/V, FD/V, FD/S(100), and FD/S(200) groups of E-300 rats ( $\mathrm{n}=5$ animals/ groupRepresentative target protein Western blots are provided. ${ }^{*} \mathrm{p}<0.05$ compared to FF/V; $* * \mathrm{p}<0.05$ versus $\mathrm{FD} / \mathrm{V}$. 


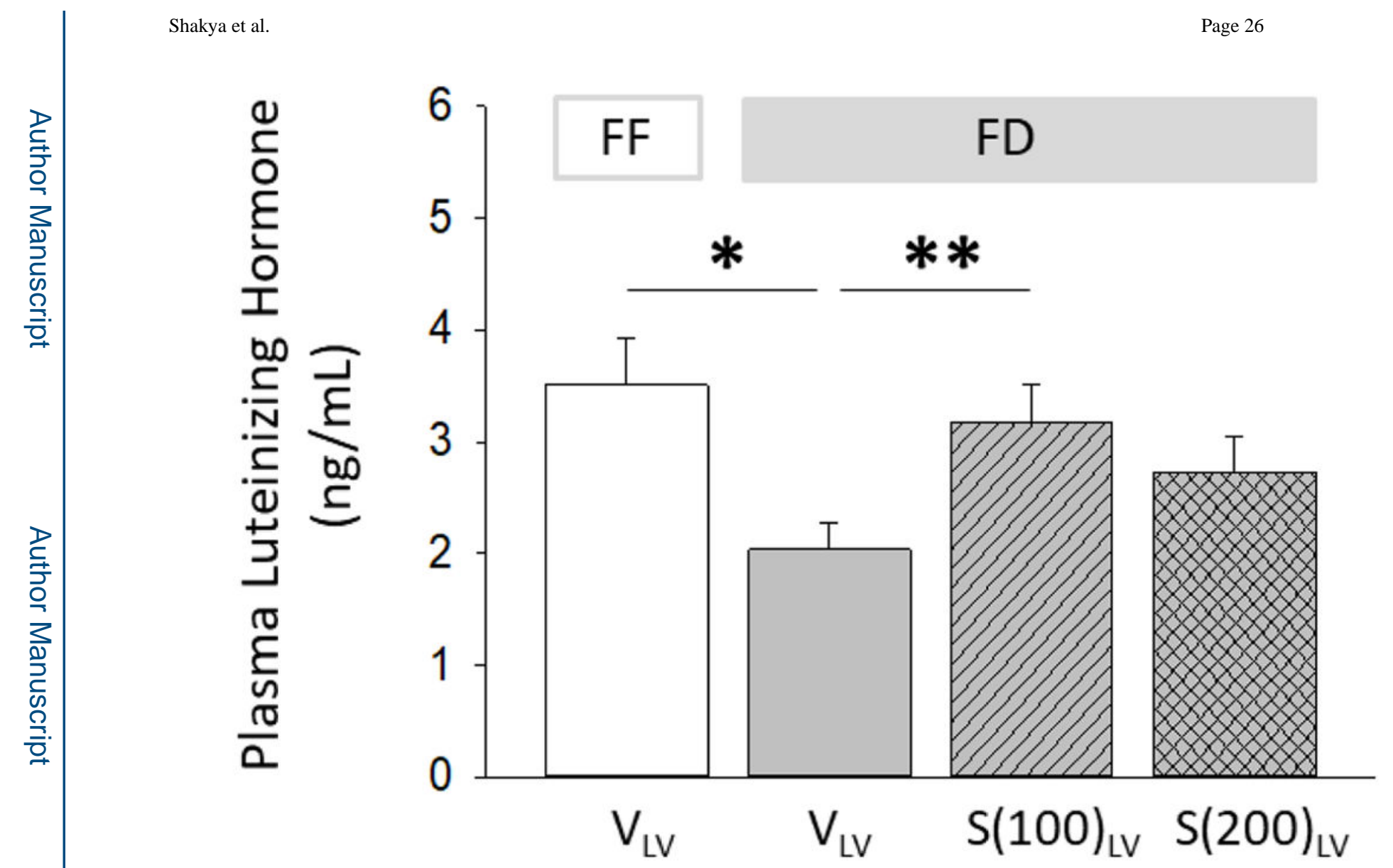

Figure 7. Effects of FD, with or without LV SIN-1 Administration, on Pituitary Luteinizing Hormone (LH) Secretion in FD-Exposed E-300 OVX Rats

Bars depict mean plasma LH concentrations \pm S.E.M. for FF/V, FD/V, FD/S(100), and FD/ $\mathrm{S}(200)$ groups of E-300 rats. *p<0.05 compared to FF/V; **p<0.05 versus FD/V. 


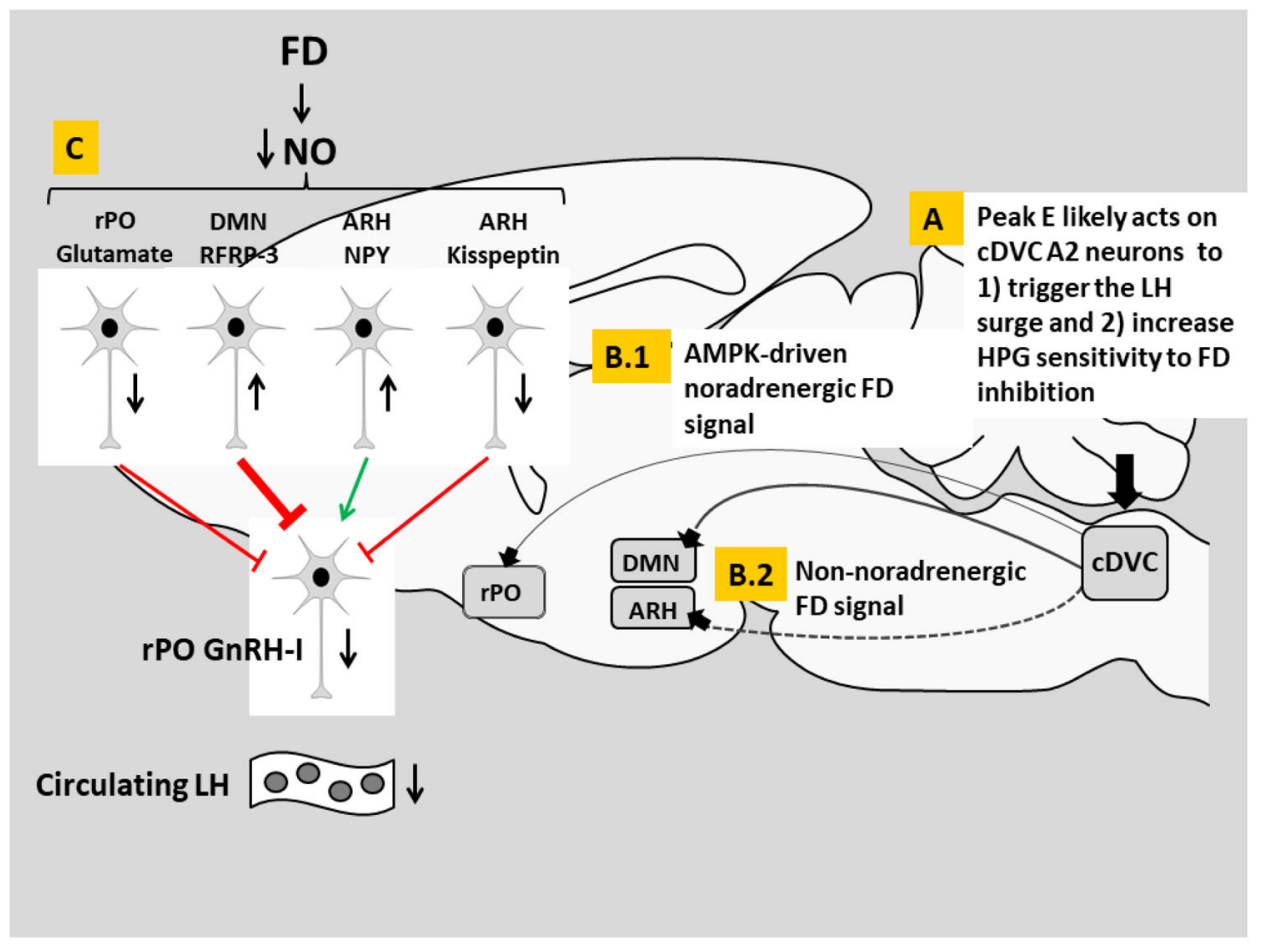

Figure 8. Model for Caudal Hindbrain Metabolic Sensor Regulation of the Pituitary LH Surge in FD Female Rats

Current data show that FD curtails steroid positive-feedback activation of the HPG axis through caudal hindbrain AMPK-dependent mechanisms. ER-expressing A2 noradrenergic neurons are a probable source of E concentration-sensitive AMPK cues during FD [Insert A]. E stimulus strength also likely establishes forebrain targets of FD-initiated NE [Insert B. 1] and non-NE [Insert B.2] signals. Neural networks that impose caudal hindbrain metabolic inhibition of rPO GnRH-I neurons in the presence of peak E likely involve NO signaling [Insert C], which may function upstream of one or more neurotransmitters (e.g. rPO glutamate, DMN RFRP-3, ARH NPY, ARH kisspeptin) identified here by SIN-1 - reversible inhibitory responses to FD. 